\title{
ARTICLE
}

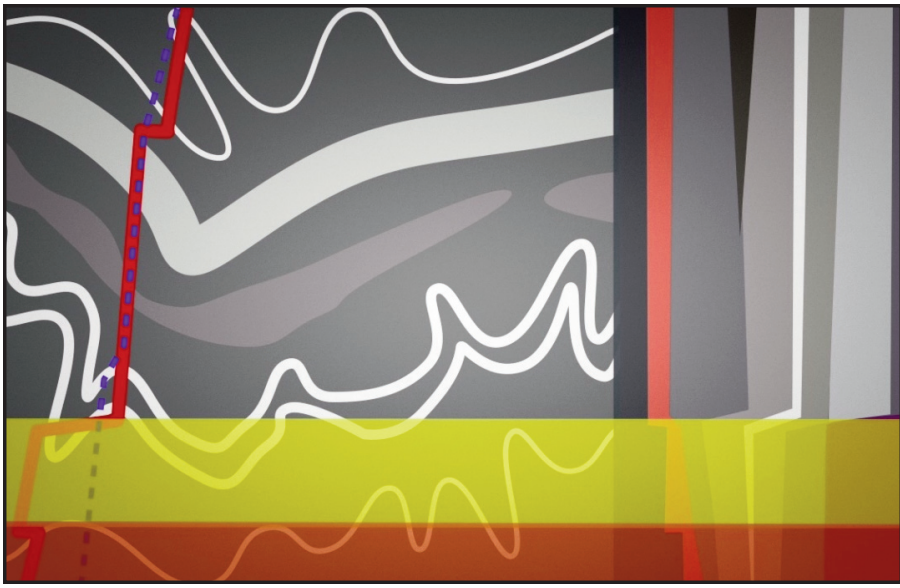

\section{Applying Phase Equilibria Modelling to Metamorphic and Geological Processes: Recent Developments and Future Potential}

\section{Chris Yakymchuk}

\author{
Department of Earth and Environmental Sciences \\ University of Waterloo, 200 University Ave West \\ Waterloo, Ontario, N2L 3G1, Canada \\ Email:cyakymchuk@uwaterloo.ca
}

\section{SUMMARY}

Phase equilibria modelling has played a key role in enhancing our understanding of metamorphic processes. An important breakthrough in the last three decades has been the ability to construct phase diagrams by integrating internally consistent datasets of the thermodynamic properties of minerals, fluids and melts with activity-composition models for mixed phases that calculate end-member activities from end-member proportions. A major advance in applying phase equilibria modelling to natural rocks is using isochemical phase diagrams to explore the phase assemblages and reaction sequences applicable for a particular sample. The chemical systems used for modelling phase equilibria are continually evolving to provide closer approximations to the natural compositions of rocks and allow wider varieties of compositions to be modelled. Phase diagrams are now routinely applied to metasedimentary rocks, metabasites and intermediate to felsic intrusive rocks and more recently to ultramafic rocks and meteorites.
While the principal application of these phase diagrams is quantifying the pressure and temperature evolution of metamorphic rocks, workers are now applying them to other fields across the geosciences. For example, phase equilibria modelling of hydrothermal alteration and the metamorphism of hydrothermally altered rocks can be used to determine 'alteration vectors' to hydrothermal mineral deposits. Combining the results of phase equilibria of rock-forming minerals with solubility equations of accessory minerals has provided new insights into the geological significance of $\mathrm{U}-\mathrm{Pb}$ ages of accessory minerals commonly used in geochronology (e.g. zircon and monazite). Rheological models based on the results of phase equilibria modelling can be used to evaluate how the strength of the crust and mantle can change through metamorphic and metasomatic processes, which has implications for a range orogenic processes, including the localization of earthquakes. Finally, phase equilibria modelling of fluid generation and consumption during metamorphism can be used to explore links between metamorphism and global geochemical cycles of carbon and sulphur, which may provide new insights into the secular change of the lithosphere, hydrosphere and atmosphere.

\section{RÉSUMÉ}

La modélisation des équilibres de phases a joué un rôle clé dans l'amélioration de notre compréhension des processus métamorphiques. Une percée importante au cours des trois dernières décennies a été la capacité de construire des diagrammes de phase en y intégrant des ensembles de données cohérentes des propriétés thermodynamiques des minéraux, des fluides et des bains magmatiques avec des modèles d'activité-composition pour des phases mixtes qui déduisent l'activité des membres extrêmes à partir des proportions des membres extrêmes. Une avancée majeure dans l'application de la modélisation d'équilibre de phase aux roches naturelles consiste à utiliser des diagrammes de phases isochimiques pour étudier les assemblages de phase et les séquences de réaction applicables pour un échantillon particulier. Les systèmes chimiques utilisés pour la modélisation des équilibres de phase évoluent continuellement pour fournir des approximations plus proches des compositions naturelles des roches et permettent de modéliser de plus grandes variétés de compositions. Les diagrammes de phase sont maintenant appliqués de façon routinière aux roches métasédimentaires, aux métabasites et aux roches intrusives intermédiaires à felsiques et plus récemment aux roches ultramafiques et aux météorites. 
Bien que l'application principale de ces diagrammes de phase consiste à quantifier l'évolution de la pression et de la température des roches métamorphiques, les utilisateurs les appliquent maintenant à d'autres spécialités des géosciences. Par exemple, la modélisation des équilibres de phase de l'altération hydrothermale et du métamorphisme des roches d'altération hydrothermale peut être utilisée pour déterminer les « vecteurs d'altération » des gisements minéraux hydrothermaux. La combinaison des résultats des équilibres de phase des minéraux constitutifs des roches avec des équations de solubilité des minéraux accessoires a permis d'en savoir davantage sur la signification géologique des âges U-Pb des minéraux accessoires couramment utilisés en géochronologie (par exemple zircon et monazite). Les modèles rhéologiques basés sur les résultats de la modélisation des équilibres de phase peuvent être utilisés pour évaluer comment la résistance de la croûte et du manteau peut changer à travers des processus métamorphiques et métasomatiques, ce qui a des implications sur une gamme de processus orogéniques, y compris la localisation des séismes. Enfin, la modélisation des équilibres de phase de la génération et de l'absorption des fluides pendant le métamorphisme peut être utilisée pour explorer les liens entre le métamorphisme et les cycles géochimiques globaux du carbone et du soufre, ce qui peut fournir de nouvelles perspectives sur le changement séculaire de la lithosphère, de l'hydrosphère et de l'atmosphère.

Traduit par le Traducteur

\section{INTRODUCTION}

Phase diagrams are graphical representations of the phases that coexist in a system as a function of different thermodynamic variables. In metamorphic geology, phase diagrams are commonly used to evaluate the absolute pressures $(P)$ and temperatures $(T)$ experienced by metamorphic rocks from which their geodynamic settings can be inferred (e.g. England and Thompson 1984; Spear 1995; Brown 2007, 2014). These diagrams are also combined with the results of accessory or major mineral geochronology to elucidate the $P$-T-time $(t)$ paths experienced by metamorphic rocks (e.g. petrochronology; Mottram et al. 2014; Ambrose et al. 2015; Stevens et al. 2015; Dragovic et al. 2016). However, metamorphic phase diagrams have much broader applications across the geosciences.

Here, I review some recent applications of phase equilibria modelling of metamorphic rocks and processes and discuss some of the broader implications of these studies. First, I review some basics of phase equilibria modelling and phase diagrams. Second, I present some of the recent applications of phase equilibria modelling to different fields of the geosciences, including tectonics, earthquakes, linking deep mantle petrology with the observations from geophysics, mineral deposits and hydrothermal alteration, the behaviour of accessory minerals, metamorphism of meteorites, and linking fluid production in metamorphic rocks to global geochemical cycles. Finally, I discuss some of the assumptions and limitations of applying the equilibrium approach to understanding metamorphic processes. A review by Spear et al. (2016) pro- vides an excellent summary of additional advances in metamorphic geology over the last 50 years and discusses some outstanding questions to be addressed in this evolving field of research.

\section{PHASE DIAGRAMS}

\section{Phase Equilibria Modelling}

Phase equilibria modelling can be used to predict the stable metamorphic phase assemblage in a rock for a set of thermodynamic variables (usually variations in $P$ and $T$ ). Note that I prefer the term phase assemblage to mineral assemblage because most metamorphic assemblages develop with a fluid and/or melt phase in equilibrium with the mineral assemblage and this needs to be considered in phase equilibria modelling. Constructing phase diagrams that display equilibrium phase assemblages requires an understanding of the phase rule and of equilibrium thermodynamics (e.g. Powell 1978; Spear 1995) that is beyond the scope of this contribution. There are several resources that provide good introductions to the fundamentals of phase equilibria including short-course notes by R. Powell (1991) on the THERMOCALC website (http://www.metamorph.geo.uni-mainz.de/thermocalc/) and the textbooks by Spear (1995) and Vernon and Clarke (2008). Here, I provide a general overview of the common types of phase diagrams, discuss some recent examples, and explore how the results of phase equilibria modelling can be linked to various geological processes. Throughout, I assume that the modelled system has achieved equilibrium, meaning that the proportions and compositions of all phases in a system (e.g. rock) at a given set of conditions (usually $P$ and $T$ ) reflect the minimum free energy configuration. This is a main principle of phase equilibria modelling. The limitations of applying this approach to natural systems are discussed later.

Phase diagrams are graphical representations of the equilibrium phase assemblages in a system as a function of intensive and/or extensive variables (e.g. Powell et al. 2005). Intensive variables are independent of the amount of material in a system, and are identical in all parts of an equilibrated system. Examples of these are temperature, pressure and chemical potential that are equalized in metamorphic systems through conduction, deformation and diffusion, respectively. Extensive variables depend on the number of moles of the components in the system (e.g. volume, entropy, composition).

The majority of metamorphic phase diagrams use intensive variables as axes (mostly $P$ and $T$ ) because these are the most useful diagrams for linking metamorphic phase assemblages to tectonic processes and to tectonic models of orogenesis. Such tectonic models can predict the pressure-temperature $(P-T)$ paths of different tectonic processes and against which constraints from phase equilibria modelling and geochronology can be evaluated (e.g. England and Thompson 1984; Thompson and England 1984; Jamieson et al. 1996, 1998, 2004, 2010). Phase diagrams with extensive variables as axes are less common but are particularly useful for investigating metamorphic processes, such as evaluating volume changes in metamorphic 
systems (e.g. Powell et al. 2005; Guiraud and Powell 2006) and modelling the redox budget of metamorphic rocks (e.g. Evans et al. 2013).

\section{Petrogenetic Grids}

Metamorphic phase diagrams have evolved in complexity since their conception in the early half of the $20^{\text {th }}$ century. Bowen (1940) was one of the first researchers to project a series of univariant equilibrium curves onto a $P-T$ plane to evaluate the metamorphic reactions that can occur over a range of pressures and temperatures. The projection of all of these univariant curves onto a common surface results in a network of lines (and points) that define a petrogenetic grid for the modelled chemical system. The topology of these diagrams can be constrained using the method of Schreinemakers (e.g. Zen 1966).

Bowen (1940) modelled the metamorphic reactions of siliceous limestone and dolostone in the relatively simple $\mathrm{CaO}-\mathrm{MgO}-\mathrm{SiO}_{2}-\mathrm{CO}_{2}$ chemical system. Over the latter part of the $20^{\text {th }}$ century, phase diagrams in larger chemical systems were developed and applied to a wider variety of rock types. Petrogenetic grids were constructed and refined using a combination of experimental studies of metamorphic reactions (e.g. Carrington and Harley 1995) and natural equilibrated phase assemblages (e.g. Pattison and Harte 1985). Grids applicable to metapelitic rocks were constructed in the $\mathrm{K}_{2} \mathrm{O}-\mathrm{FeO}$ $\mathrm{MgO}-\mathrm{Al}_{2} \mathrm{O}_{3}-\mathrm{SiO}_{2}-\mathrm{H}_{2} \mathrm{O}$ (KFMASH) system (e.g. Albee 1965). Following on from this work the chemical systems of petrogenetic grids continued to expand to become closer approximations of the true chemical composition of metamorphic rocks. The KFMASH system was expanded to include $\mathrm{Na}_{2} \mathrm{O}$ (Thompson and Algor 1977) and later $\mathrm{CaO}$ (Thompson and Tracy 1979), which were critical for modelling the anatexis of pelitic rocks.

Other important components were later included in petrogenetic grids, such as manganese, which is of particular importance for garnet-bearing univariant equilibria (e.g. Spear and Cheney 1989; Symmes and Ferry 1992; Tinkham and Ghent 2005; White et al. 2005), and ferric iron and titanium, which allowed Fe-Ti oxides to be considered (e.g. White et al. 2007; White et al. 2014a). A wide variety of petrogenetic grids is now available to investigate rocks from low to high grade (e.g. White et al. 2014a; Kelsey and Hand 2015) and for a range of compositions (e.g. Will et al. 1990; Frey et al. 1991; Riesco et al. 2004; White et al. 2007; Groppo et al. 2013). A recent example of a petrogenetic grid constructed in the KFMASHTO system applicable for suprasolidus rocks is shown in Figure 1a. Univariant reactions are displayed as lines that connect at invariant points. All phase abbreviations in this figure and the remainder of this contribution are summarized in Table 1.

While petrogenetic grids provide an essential framework in which to understand the reactions that take place in metamorphic systems, there are two main limitations when applying them to natural rocks. The first is that petrogenetic grids are a projection of all possible univariant reactions in a specified chemical system onto a $P-T$ plane. A specific rock will only 'see' a subset of the total number of univariant reactions; the specific reactions that are encountered depend on the particu-
Table 1. Phase abbreviations used in the text and figures (from Holland and Powell 2011).

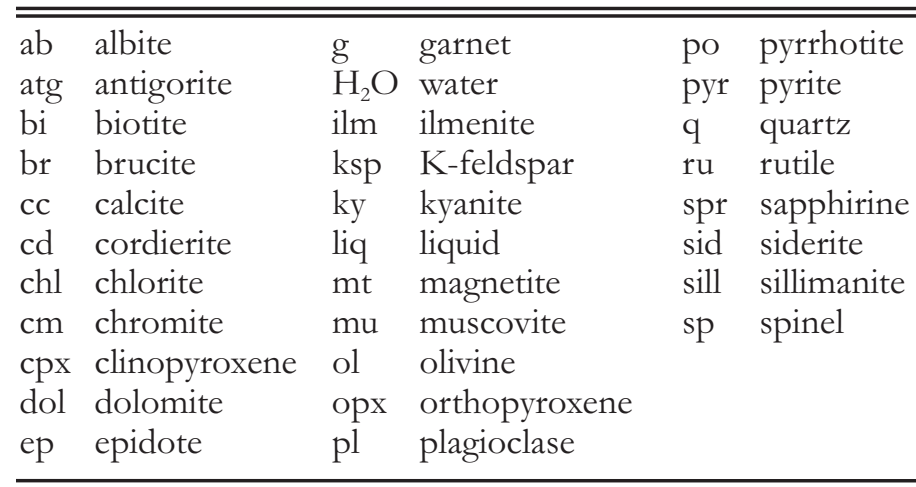

lar bulk composition of the rock. While this can be accounted for by using complementary chemographic diagrams in simple chemical systems (e.g. KFMASH; Thompson 1957), this approach does not easily lend itself to the larger chemical systems (e.g. MnNCKFMASHTO) where higher-dimensional chemographic diagrams would be required. The second limitation is that phase assemblages in metamorphic rocks generally change through continuous or multivariant reactions rather than univariant (discontinuous) reactions (e.g. Stüwe and Powell 1995). These multivariant reactions are not displayed on petrogenetic grids. Furthermore, univariant reaction curves on petrogenetic grids may yield the false impression that phase assemblages change over narrow intervals in $P-T$ space. In reality, phase proportions (also known as modes) and compositions continuously change along a $P-T$ evolution due to the operation of multivariant reactions.

\section{Isochemical Phase Diagrams}

One of the most significant advances in metamorphic geology in the last 30 years has been the development of isochemical phase diagrams that are applicable to fixed bulk rock compositions (e.g. individual rock samples). The concept goes back to Hensen (1971) who constructed schematic $P-T$ phase diagrams for particular bulk rock compositions in the $\mathrm{MgO}-$ $\mathrm{FeO}-\mathrm{Al}_{2} \mathrm{O}_{3}-\mathrm{SiO}_{2}$ chemical system. R. Powell and colleagues popularized this approach by developing the THERMOCALC software package that solves a set of independent non-linear equations to determine the stable phase assemblages (which may include minerals, fluids and/or melts) as well as their compositions and modes across a $P-T$ diagram for a fixed bulk composition (Powell et al. 1998). THERMOCALC calculates individual phase boundaries (and invariant points), which are then combined manually into complete phase diagrams. As computational power increased, automated software packages were developed to generate similar diagrams, but using Gibbs free energy minimization as the numerical method to determine the equilibrium phase assemblage (e.g. Connolly and Petrini 2002; de Capitani and Petrakakis 2010).

Phase diagrams constructed for a fixed bulk composition are called isochemical phase diagrams and have also been called psendosections in the metamorphic literature. Pseudosections are not true sections because the compositions of phases 
in the system may lie off the plane of the section (Powell 1991). Although psendosection also applies to non-isochemical phase diagrams, the term has largely become synonymous with isochemical phase diagrams. The same term is also used in geophysics to display 2-dimensional multi-electrode resistivity data (e.g. Everett 2013). To avoid confusion, I will not use this term from this point forward.

Isochemical phase diagrams consist of a series of geometric domains (e.g. panels) that are bounded by lines (Fig. 1b). Each domain represents a stable phase assemblage and these domains are commonly shaded (mainly for convenience) so that darker shades indicate relatively high-variance assemblages and lighter shades represent low-variance assemblages. Each domain is generally labelled with the stable phase assemblage.

In contrast to the lines representing reactions in a petrogenetic grid, the lines on an isochemical phase diagram represent the $P-T$ conditions where the mode of a mineral, fluid or melt goes to zero. Isochemical phase diagrams can be more powerful than petrogenetic grids because they can be contoured for phase proportions and compositions that can be used to quantify the $P-T$ conditions and the reaction sequence of a particular rock during prograde and retrograde metamorphism. These contours are commonly referred to as isopleths in the metamorphic community. This information can be combined with petrographic observations and the results of electron probe microanalysis of mineral compositions to constrain a $P$ $T$ path.

The two most important factors in constructing an isochemical phase diagram for a rock is choosing an appropriate chemical system and using a representative bulk composition for the assumed volume of equilibration. The modelled chemical system is a necessary simplification of the more complex natural system, but it should include the key components that make up the phases of interest in a sample. For example, the KFMASH system is appropriate for modelling many metapelitic rocks but the calculated equilibria would not include plagioclase. This system also does not consider manganese, which can significantly extend the stability of garnet to lower temperatures (e.g. Symmes and Ferry 1992; Mahar et al. 1997; Tinkham et al. 2003; White et al. 2014b). In general, it is good practice to model in the largest chemical system possible, which represents the closest approximation to the natural rock composition.

Bulk composition can be determined in several ways: (1) crushed and milled rock samples can be analyzed using X-ray fluorescence or other bulk analytical techniques, (2) major element mapping of thin sections using $\mu \mathrm{XRF}$ or scanning electron microscopy (e.g. Indares et al. 2008), and (3) combining point counting or automated mineral mode analysis (e.g. QEMSCAN and MIL) with mineral compositions obtained by electron microprobe analysis (e.g. Carson et al. 2000; Lasalle and Indares 2014). Each of these methods has advantages and disadvantages, but the result should be a bulk composition that approximates the equilibration volume of the rock. Additional factors that need to be considered in some cases are the concentration of $\mathrm{CO}_{2}$ and $\mathrm{H}_{2} \mathrm{~S}$ in the fluid phase (Tomkins and Evans 2015), the amount of $\mathrm{H}_{2} \mathrm{O}$ in the bulk composition (e.g.
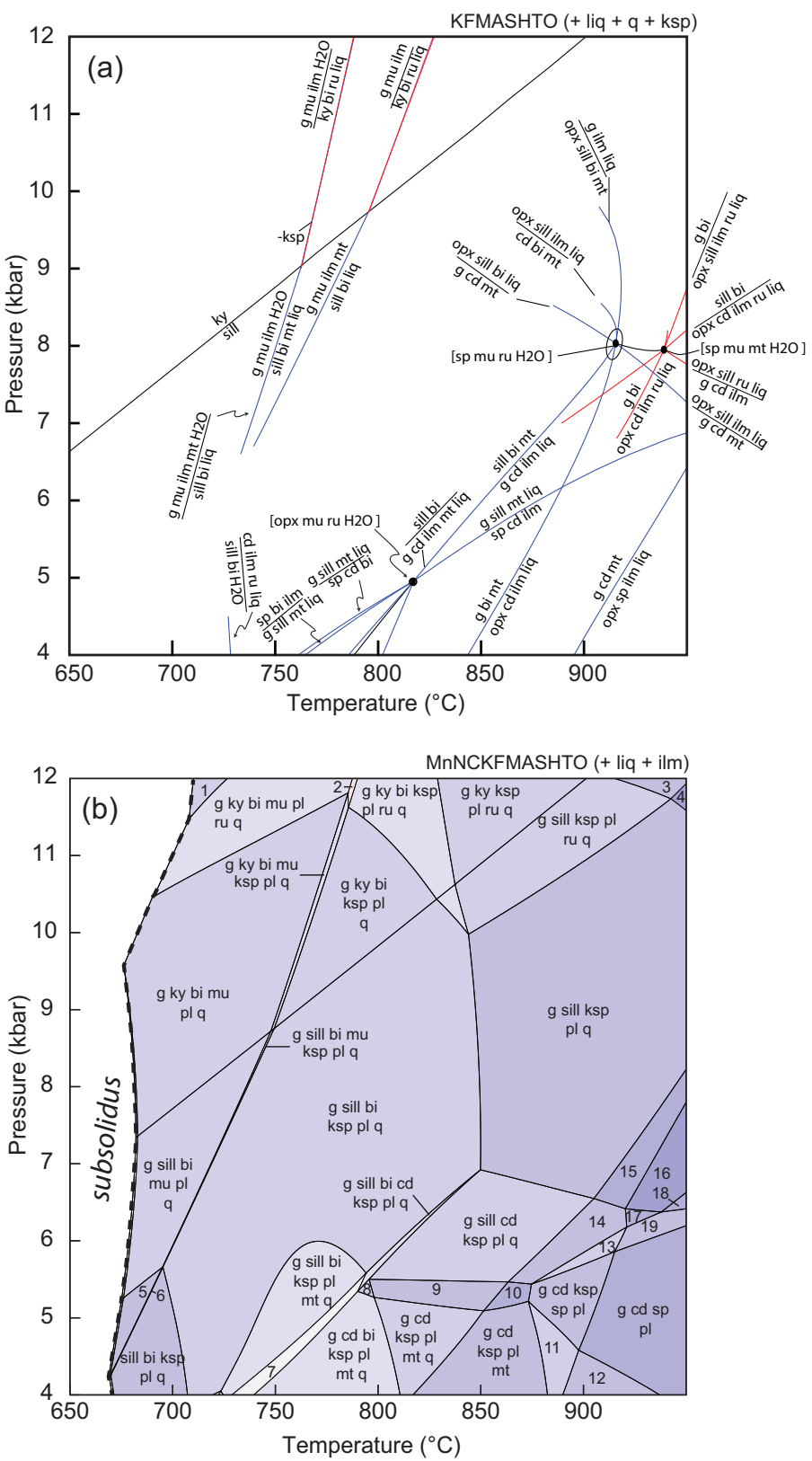

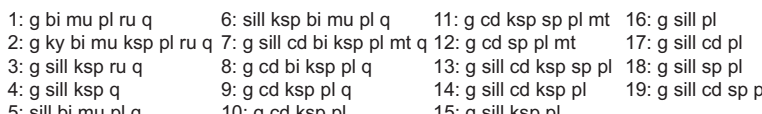

Figure 1. (a) Petrogenetic grid of selected suprasolidus univariant reactions for metapelitic rocks in the $\mathrm{K}_{2} \mathrm{O}-\mathrm{FeO}-\mathrm{MgO}-\mathrm{Al}_{2} \mathrm{O}_{3}-\mathrm{SiO}_{2}-\mathrm{H}_{2} \mathrm{O}-\mathrm{TiO}_{2}-\mathrm{O}$ system (modified from White et al. 2014a). Blue lines are for reactions that include magnetite and red lines are for reactions that include rutile. Note that some labels are omitted for clarity. (b) Isochemical $P-T$ phase diagram for the average amphibolitefacies metapelite composition of Ague (1991) and modified from Yakymchuk et al. (2017). Each field contains the equilibrium phase assemblage and each line is where the proportion of one phase goes to zero. Fields are shaded so that light shades are low-variance assemblages and dark shades represent high-variance assemblages. Silicate melt (liq) and ilmenite (ilm) are present in each field of the diagram.

White et al. 2007), as well as the oxidation state of the system (e.g. Boger et al. 2012; Evans et al. 2013).

Once a bulk composition is determined, there are two main computational approaches to constructing isochemical phase 
diagrams. Both approaches require an internally consistent thermodynamic database (e.g. Helgeson et al. 1978; Berman 1988; Holland and Powell 1998, 2011) and activity-composition models that relate end-member proportions to end-member activities for the solid-solution minerals as well as for complex fluid and melt phases (e.g. Evans et al. 2010; White et al. 2014a; Green et al. 2016).

The first computational approach is to use Gibbs free energy minimization to determine the stable phase assemblages at a given $P-T$ condition. Two common software packages available for this approach are Perple_X (Connolly and Petrini 2002; http://www.perplex.ethz.ch) and THERIAK-DOMINO (de Capitani and Brown 1987; de Capitani and Petrakakis 2010; http://titan.minpet.unibas.ch/minpet/theriak/theruser. $\mathrm{html})$. They are user-friendly and can automatically calculate most phase diagrams relatively quickly (generally minutes to hours). The output is a complete phase diagram and associated files with other calculation information. An additional benefit of Gibbs free energy minimization programs is the ability to easily explore thermodynamic data and activity-composition models of end-member activities.

A second approach is to determine the solution of simultaneous non-linear equations to build up an array of points and lines that make up a metamorphic phase diagram (THERMOCALC: Powell and Holland 1988, 2008; Powell et al. 1998). This is a more time-consuming approach, but workers acquire a deeper understanding of how phase diagrams are developed.

\section{Compositional Phase Diagrams}

The most common type of phase diagrams in metamorphic studies is isochemical P-T phase diagrams. Another class of phase diagrams is used to evaluate changes in the chemical composition of the system. In these diagrams, one or more axes represent compositional variables that can be intensive (e.g. molar ratios) or extensive (e.g. weight $\%$ or mol. \% of a component). Compositional phase diagrams include PressureComposition $(P-X)$, Temperature-Composition $(T-X)$, and Composition-Composition diagrams $(X-X)$. Figure 2 shows examples of each of these. Note that the same topological features described above for isochemical phase diagrams also apply to the compositional phase diagrams.

Figure 2. (opposite) Selection of phase diagrams calculated where one or more axes are compositional variables. (a) Pressure-Composition calculated at $890^{\circ} \mathrm{C}$ showing the sensitivity of phase assemblages in pelite to the oxidation ratio, which is defined as molar $\left(\left[2 \times \mathrm{Fe}_{2} \mathrm{O}_{3} \times 100\right] /\left[2 \mathrm{Fe}_{2} \mathrm{O}_{3}+\mathrm{FeO}\right]\right)$. The vertical axis on the left-hand side of the diagram is for metapelite with $\sim 1 \%$ of iron in the ferric state and the righthand side is the same metapelite but with roughly $\sim 33 \%$ of the iron in the ferric state. Note that the oxidation ratio affects the stability of oxides (e.g. magnetite) and silicate minerals (e.g. garnet and sillimanite). Modified from Boger et al. (2012). (b) Temperature-Composition phase diagram calculated at $10 \mathrm{kbar}$ for sapphirine-quartz granulite (modified from Korhonen et al. 2012). The horizontal axis is the amount of $\mathrm{H}_{2} \mathrm{O}$ in the modelled bulk composition ranging from $0 \mathrm{~mol} \%$ (left side) to 1.34 mol. $\%$ (right side). The solidus (dashed line) is sensitive to the amount of $\mathrm{H}_{2} \mathrm{O}$. (c) Composition-Composition diagram calculated at $1.5 \mathrm{kbar}$ and $320^{\circ} \mathrm{C}$ for greenschistfacies metabasite (with a constant fluid composition of $X_{\mathrm{CO} 2}=0.25$ ) from an orogenic gold deposit illustrating the sensitivity of carbonate minerals to the bulk composition of $\mathrm{K}_{2} \mathrm{O}$ on the vertical axis and the relative amount of $\mathrm{Fe}$ to $\mathrm{Mg}$ on the horizontal axis (modified from White et al. 2003).
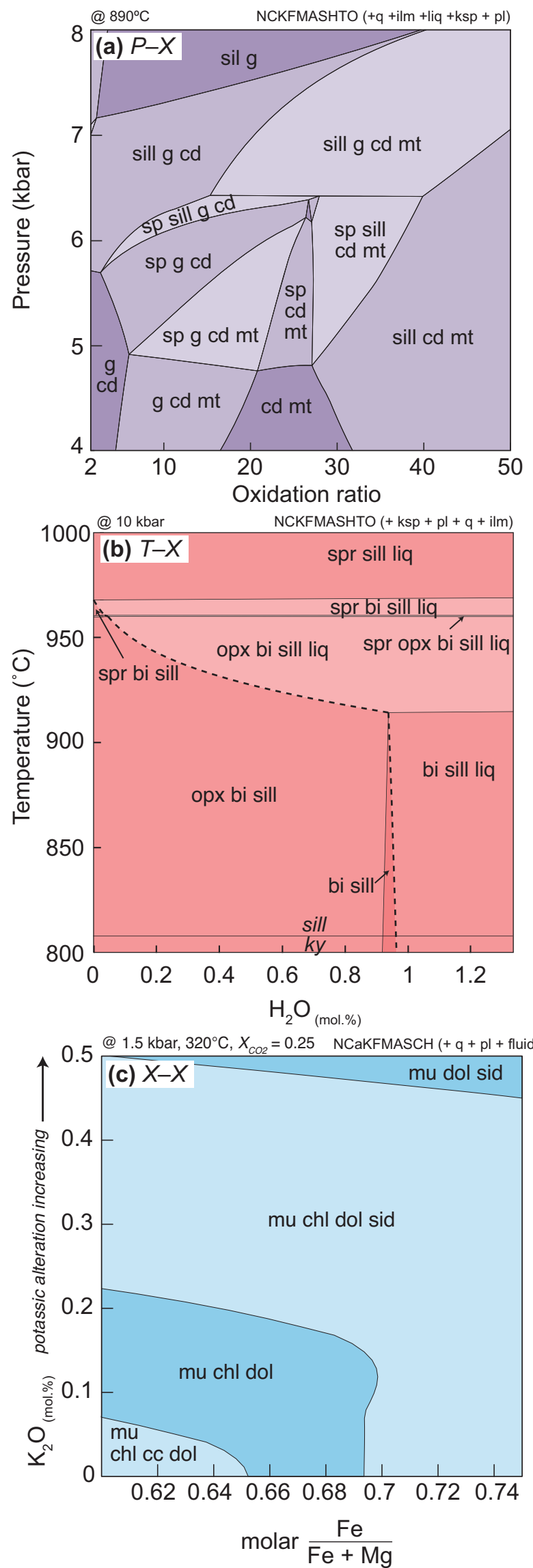

https://doi.org/10.12789/geocanj.2017.44.114 
The $P-X$ diagram in Figure $2 \mathrm{a}$ is from Boger et al. (2012) and has $P$ on the vertical axis (similar to most $P-T$ phase diagrams) and the horizontal axis relates to the ratio of ferric to ferrous iron in the bulk composition, which is a proxy for the oxidation state of the system. Here the diagram illustrates that the stability of oxide (e.g. magnetite) and silicate minerals (e.g. garnet and sillimanite) is sensitive to changes in the oxidation state of the system. For example, garnet is stable and magnetite is unstable over the modelled pressure range for relatively reducing systems (left side of diagram), whereas on the right side of the diagram the opposite is true.

A $T-X$ diagram from Korhonen et al. (2012) in Figure 2b illustrates the sensitivity of the solidus temperature in a metasedimentary rock to changes in bulk rock water content. The solidus is at higher temperatures for drier bulk compositions (left side of the diagram). A prediction of this phase diagram is that melting can initiate due to an increase in the proportion of water in the system at a constant temperature. For example, the addition of $\sim 1 \mathrm{~mol} . \%(\sim 0.4 \mathrm{wt} . \%)$ of $\mathrm{H}_{2} \mathrm{O}$ to a completely dry rock at $900^{\circ} \mathrm{C}$ will cause it to melt at $<800^{\circ} \mathrm{C}$.

While not common, $X-X$ diagrams are particularly useful in studies of hydrothermal alteration and metasomatism (e.g. White et al. 2003; Riesco et al. 2005). An example from White et al. (2003) is shown in Figure 2c. This diagram was calculated at $1.5 \mathrm{kbar}$ at $320^{\circ} \mathrm{C}$ with a constant fluid composition of $X_{\mathrm{CO} 2}$ $=0.25$ (molar $\mathrm{CO}_{2} /\left[\mathrm{H}_{2} \mathrm{O}+\mathrm{CO}_{2}\right]$ ). Here the vertical axis represents the molar proportion of $\mathrm{K}_{2} \mathrm{O}$ in the bulk composition. Higher values approximate the degree of potassic alteration. The horizontal axis extends along a range of mafic protolith compositions with variable $X_{\mathrm{Fe}}$ (molar $\left.\mathrm{Fe} /[\mathrm{Fe}+\mathrm{Mg}]\right)$. Note that in some cases an equivalent amount of potassic alteration will produce the same alteration minerals (e.g. mu+chl+dol+sid at $\mathrm{K}_{2} \mathrm{O}=0.3$ ) across the range of protolith compositions. In other scenarios, potassic alteration will produce different alteration minerals for protoliths with variable $X_{\mathrm{Fe}}$ values. For example, at a $\mathrm{K}_{2} \mathrm{O}$ value of 0.2 , siderite is stable in the high $X_{\mathrm{Fe}}$ compositions but is absent in compositions with $X_{F e}<0.64$.

\section{Volumetric Phase Diagrams}

One of the assumptions when constructing isochemical P-T phase diagrams is that changes in pressure are accommodated by changes in volume (e.g. via deformation of the rock). Likewise, we generally assume that heat flow accommodates changes in $T$. The effects of volume change are particularly important in studies of migmatites (e.g. Powell et al. 2005) and ultra-high pressure mineral assemblages (e.g. Guiraud and Powell 2006), as well as in studies of the serpentinization of ultramafic rocks (Kelemen and Hirth 2012).

For a $P-T$ isochemical phase diagram to be an effective model of a natural system, we assume that the rock deforms relatively quickly to maintain a constant pressure. Melt is a relatively high-volume phase relative to most silicate minerals and the production of melt can potentially induce large volume changes in a rock. For some rock types, such as metabasite and some greywackes, melt is predicted to be produced more or less continuously along a prograde $P-T$ path (e.g. Johnson et al. 2008; Yakymchuk and Brown 2014a; Palin et al. 2016b).
However, rocks such as metapelite also contain narrow lowvariance fields. In these fields, melt is generated over relatively small temperature intervals, which potentially represents a more pulsed nature of melt generation. In these cases, a relatively small increase in temperature is predicted to generate a large quantity of melt resulting in a correspondingly large volume increase.

Some of these aspects were explored by Powell et al. (2005) for a model aluminous metapelite composition. An isochemical $P-T$ phase diagram for this composition is shown in Figure $3 \mathrm{a}$ and it is contoured for molar volume. A complementary Volume-Temperature diagram from Powell et al. (2005) is shown in Figure 3b. Note that the volume is presented as molar volume. The diagram is contoured for isobars (lines of constant pressure) to illustrate the changes in volume that occur at different pressures during isobaric heating. Consider an isobaric heating path at $5 \mathrm{kbar}$. There are two nearly vertical segments (one at $\sim 680^{\circ} \mathrm{C}$ and one at $\sim 725^{\circ} \mathrm{C}$ ) that relate to the relatively low-variance fields that represent muscovite and biotite breakdown. As the isobaric path crosses these fields there is a large volume change due to melt generation. If this relatively rapid volume increase cannot be accommodated by local deformation in the rock's environment, then the rock will respond to the increase in melt volume and concomitant pressure increase by fracturing or otherwise deforming to allow the melt to escape, thereby re-establishing the ambient lithostatic pressure. If melt is lost, the composition of the residue will change and the isochemical phase diagrams calculated for the protolith composition (Fig. 3a, b) are no longer valid. Some techniques for accounting for melt loss are discussed later.

\section{SOME RECENT APPLICATIONS OF PHASE EQUILIBRIA MODELLING}

\section{$\boldsymbol{P}-\boldsymbol{T}$ Determinations in Metamorphic Rocks}

One of the principal applications of isochemical phase diagrams is linking the observed phase assemblages, reaction sequences and phase modes and compositions to the $P-T$ conditions of metamorphism. Figure 4 is an example of an isochemical P-T phase diagram from Pearce et al. (2015a) for a greywacke composition that is contoured for the $X_{F e}$ (molar $\mathrm{Fe} /[\mathrm{Fe}+\mathrm{Mg}])$ of chlorite. For the example in Figure 4, note that the $X_{\mathrm{Fe}}$ isopleths for chlorite are generally steeply dipping. This indicates that this parameter is mostly sensitive to changes in temperature. For the modelled rock, a peak assemblage of epidote-chlorite-albite (plus the other phases that are stable across the diagram) and a chlorite $X_{F e}$ value of 0.60 would constrain the $P-T$ conditions to $P>6 \mathrm{kbar}$ at $\sim 350^{\circ} \mathrm{C}$. Isopleths for other parameters can also be used to refine these $P-T$ estimates.

While mineral composition isopleths are useful for lowtemperature metamorphic rocks, their use at high temperatures is complicated by retrograde exchange reactions during cooling that change the compositions of the minerals from what they were at peak conditions (e.g. Indares and Martignole 1985; Spear and Florence 1992; Pattison and Bégin 1994; Kohn and Spear 2000; Pattison et al. 2003). For these rocks, a better 

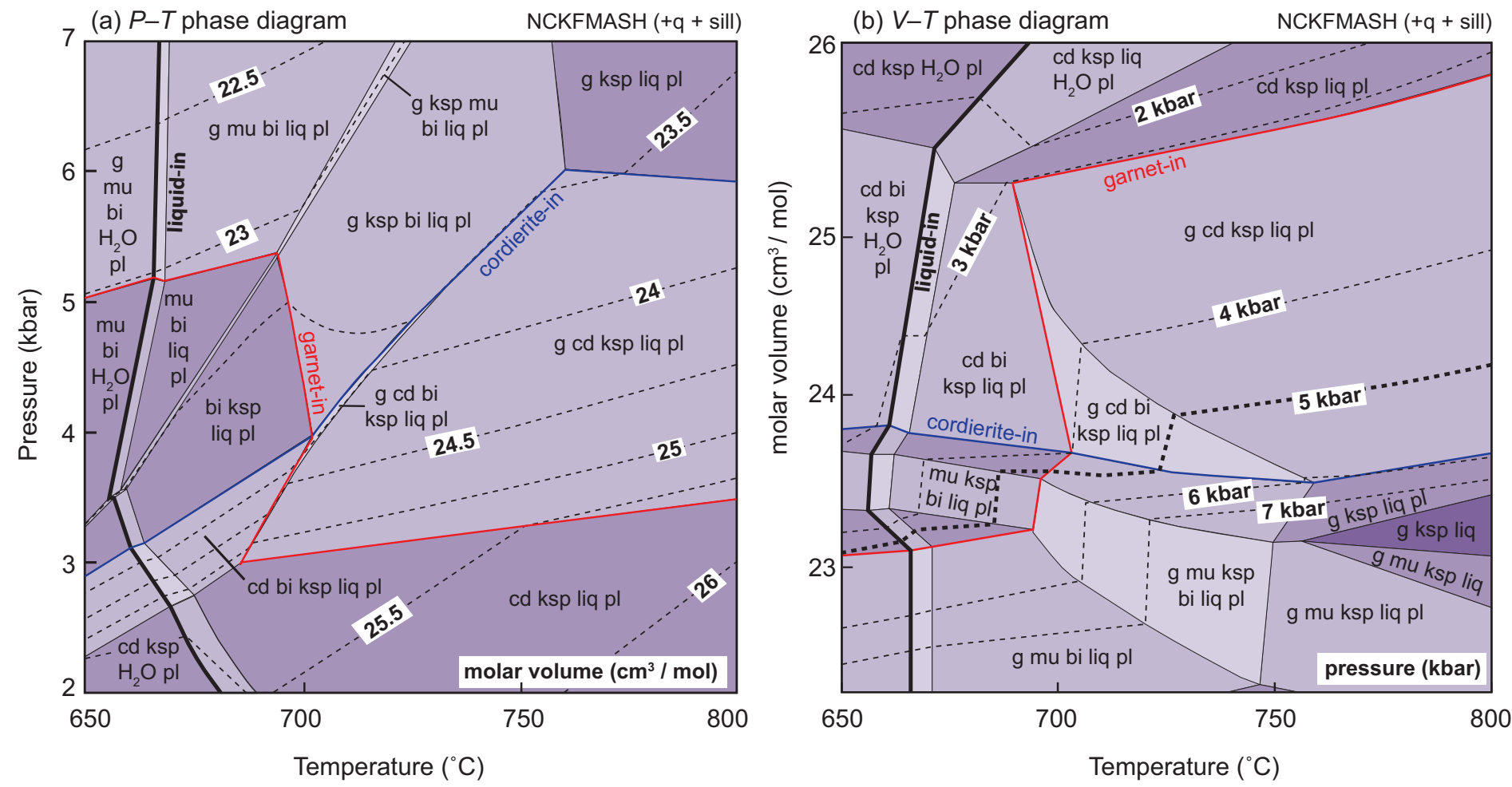

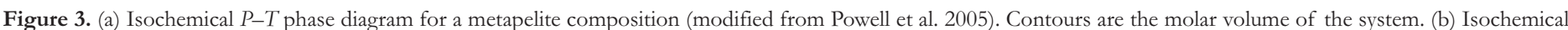

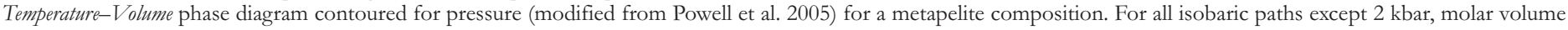

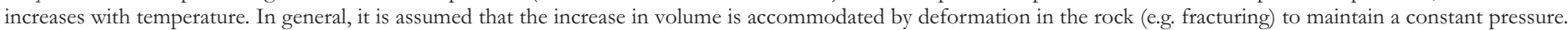

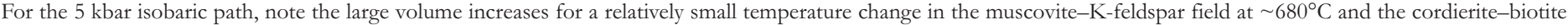
field at $\sim 725^{\circ} \mathrm{C}$. These relatively rapid volume changes may be accommodated by deformation or the expulsion of high-volume melt from the rock.

approach is to use the preserved assemblage to determine the conditions of peak metamorphism and the modes of various minerals to constrain the $P-T$ path.

A simple example of using mode isopleths to interpret a $P-$ $T$ path is shown in Figure 5 for a metasedimentary migmatite from Yakymchuk et al. (2015). Here, the peak pressure assemblage contains biotite, garnet, sillimanite and liquid, which defines a field of $850-900^{\circ} \mathrm{C}$ at $P>7-7.5 \mathrm{kbar}$ (Fig. 5a). The microstructures in the rock suggest the consumption of biotite, garnet and sillimanite to produce cordierite (see inset in Fig. 5a). The $P-T$ field for the cordierite-bearing assemblage is restricted to $840-890^{\circ} \mathrm{C}$ at $6-7.5 \mathrm{kbar}$, which is at a slightly lower pressure than the earlier garnet-biotite-sillimanite assemblage. A schematic $P-T$ path was constructed to connect these two assemblage fields and the mineral and melt modes were calculated along this path. The Pressure-Mode diagram in Figure $5 \mathrm{~b}$ summarizes the oxide-molar proportions (approximately equivalent to vol. $\%$ of phases in a rock) along the decompression path. The modelling predicts that garnet, biotite and sillimanite are consumed to produce cordierite and melt during decompression, which links well with the inferred petrogenesis.

\section{Mineral Deposits and Hydrothermal Alteration}

Phase equilibria modelling can be used to understand the genesis of mineral deposits in both direct and indirect ways. Some ore-forming processes can be directly modelled using phase diagrams, such as the role of partial melting and melt extraction on upgrading magnetite and hematite concentrations in iron ore (e.g. Morrissey et al. 2016). Other scenarios can be modelled that are indirectly associated with mineralizing systems. For example, isochemical $P-T$ phase diagrams can be used to assess the quantity of melt generated from different protoliths and the melting reactions that are responsible for generating the magmas that ultimately differentiate to form uranium deposits (e.g. Jeanneret et al. 2016).

Phase equilibria modelling can also be used to (1) predict alteration mineral assemblages (e.g. Elmer et al. 2007, 2008; Evans et al. 2013; White et al. 2013, 2014c), (2) assess how metamorphic assemblages develop in hydrothermally altered rocks (e.g. Pattison and Seitz 2012), (3) determine the compositions of fluids released during metamorphic reactions (White et al. 2003; Phillips and Powell 2010), and (4) quantify the amounts of mineralizing fluids responsible for forming hydrothermal ore deposits (e.g. Pearce et al. 2015b). These applications of phase equilibria modelling can provide 'alteration vectors' to mineralization because alteration zones around hydrothermal mineral deposits are usually much larger than ore zones.

One of the strengths of phase equilibria modelling is that a wide variety of alteration styles (e.g. carbonatization, potassic alteration, fenitization, silicification) can be examined in numerous rock types at different $P-T$ conditions. The outputs of phase equilibria modelling can provide predictions of alter- 


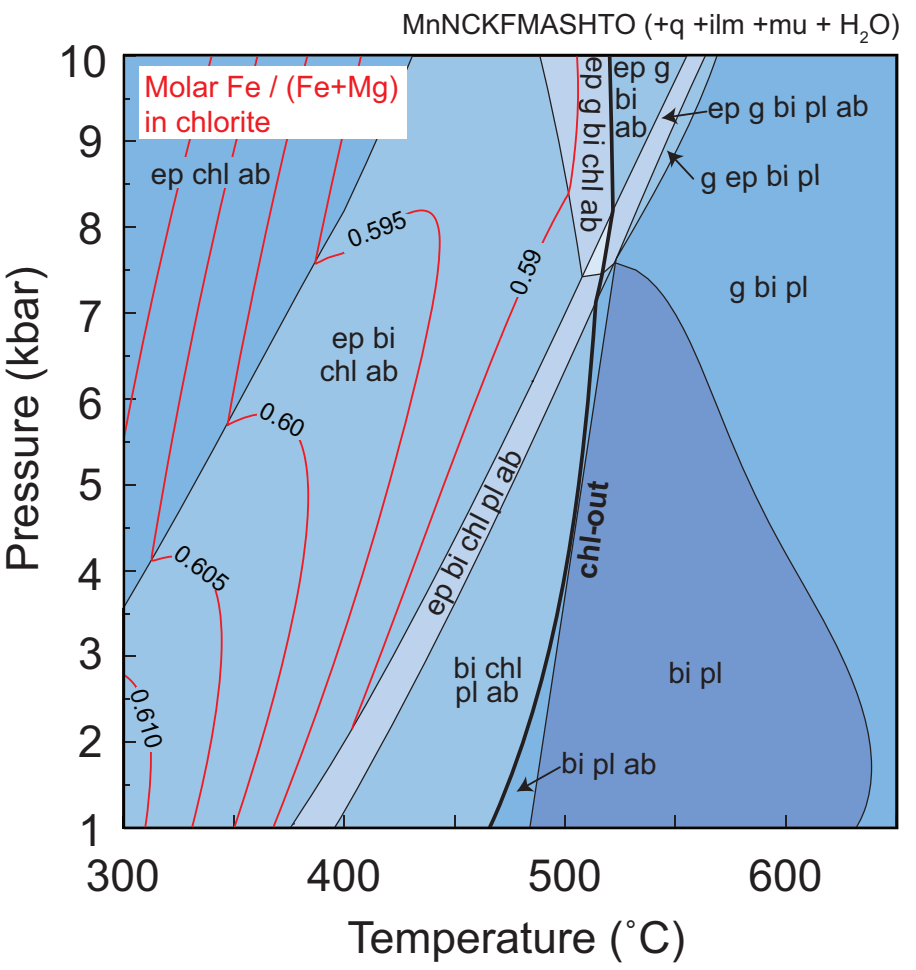

Figure 4. Pressure-Temperature isochemical phase diagram for a metagreywacke contoured for the value of $X_{\mathrm{Fe}}$ (molar $\left.\mathrm{Fe} /[\mathrm{Fe}+\mathrm{Mg}]\right)$ in chlorite (modified from Pearce et al. 2015a). The chlorite composition isopleths are generally steeply sloping, which indicates that this variable is sensitive to temperature in this example. The modelled plagioclase is roughly oligoclase in composition, which is predicted to coexist with albite reflecting the 'peristerite gap' (e.g. Vry et al. 2008)

ation at several levels of detail ranging from the mineral assemblage (outcrop scale), to mineral modes (core and hand sample scale) to mineral compositions (thin section scale).

White et al. (2003) applied phase equilibria modelling to investigate potassic alteration of greenschist-facies metabasites that host orogenic gold mineralization in the Kalgoorlie area of Western Australia. Orogenic gold mineralization at Kalgoorlie is associated with carbonic and potassic alteration zones. Figure 6a shows a temperature-composition phase diagram where the amount of potassium in the bulk rock ranges from negligible at the left side of the diagram to strong potassic alteration at the right. Consider a constant temperature of $310^{\circ} \mathrm{C}$ on this diagram, which is approximately the temperature of gold deposition at Kalgoorlie (White et al. 2003). With increasing potassic alteration (e.g. $\mathrm{K}_{2} \mathrm{O}$ being introduced into the rock by an externally derived fluid) chlorite eventually disappears from the assemblage when the amount of $\mathrm{K}_{2} \mathrm{O}$ in the bulk rock reaches $\sim 3.2$ mol.\% (Fig. 6a). While this is of some use to an exploration geologist, a more detailed model of the amounts of key alteration minerals is shown in Figure 6b. In this diagram, the modes of alteration minerals vary as potassic alteration increases. The amounts of muscovite and siderite increase during potassic alteration at the expense of chlorite, plagioclase and dolomite. At the far right of this diagram, the amount of siderite reaches $\sim 20 \mathrm{~mol} . \%$ (roughly equivalent to 20 vol. \%), which should be apparent in hand and core samples or from the results of mineral liberation analysis (QEMSCAN (a)
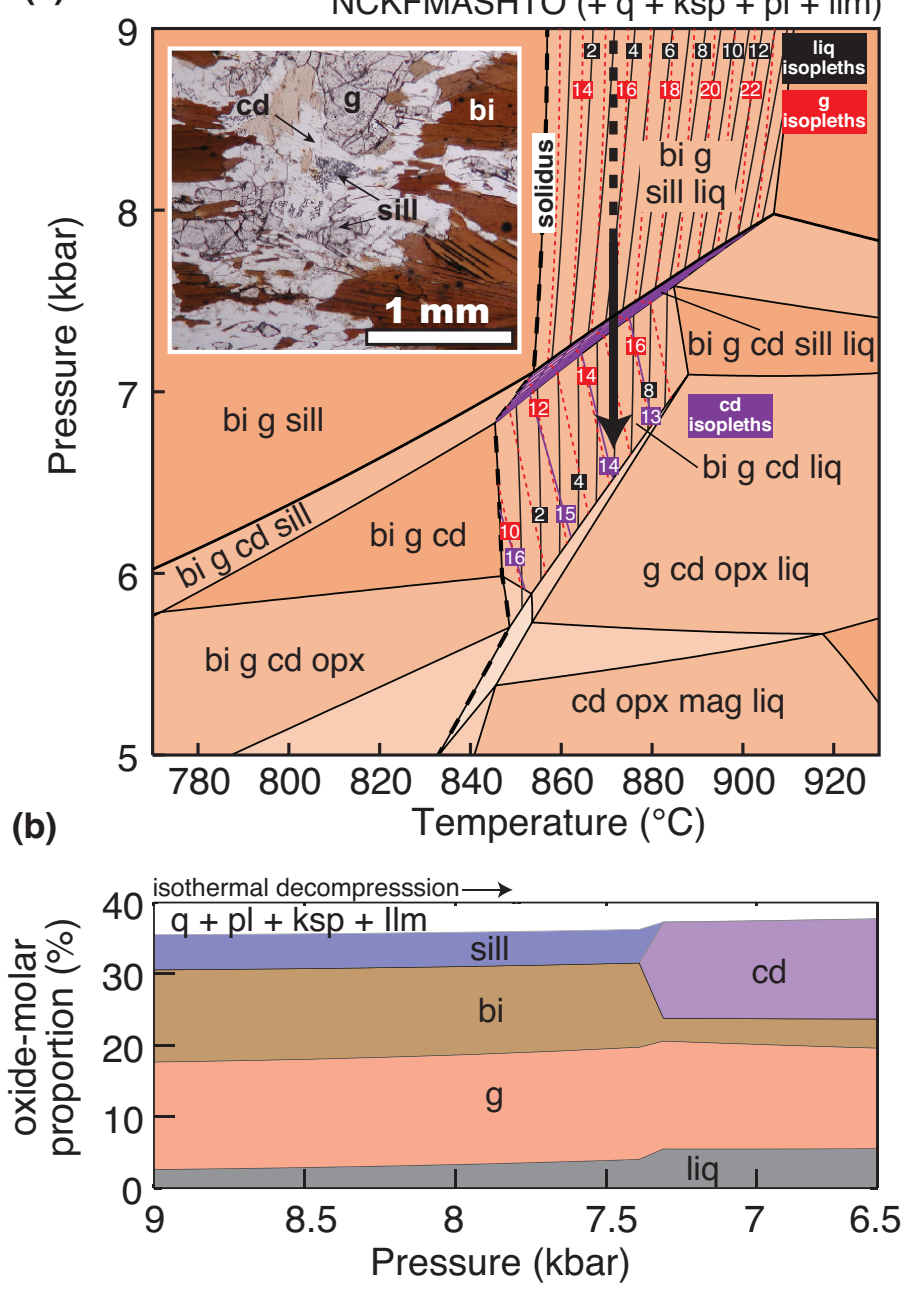

Figure 5. An example of linking the predictions of phase equilibria modelling with microstructural observations. (a) Isochemical Pressure-Temperature phase diagram for a suprasolidus metapelite (modified from Yakymchuk et al. 2015). The isopleths are for the modes of liquid, cordierite and garnet. The inset shows the breakdown of garnet, sillimanite and biotite to cordierite. A schematic isothermal decompression $P-T$ path is shown by the bold arrow. (b) Pressure-Mode diagram showing the change in the proportions of the key ferromagnesian minerals along the $P-T$ path in (a). Note that the modelling predicts the consumption of sillimanite, biotite and minor garnet to produce cordierite, which is consistent with the microstructural observations.

or MLA). Although not discussed by White et al. (2003), additional outputs from the modelling can include the composition of the different minerals (e.g. plagioclase). This information can be linked with the results of electron probe microanalysis to quantify the amount of potassic alteration.

\section{Open System Behaviour and Melt Drainage}

One of the key benefits of phase equilibria modelling is the ability to model a large number of petrogenetic scenarios, which can be prohibitively time-consuming for experimental petrologists. An example of this is modelling open-system behaviour in migmatites. The preservation of high-grade metamorphic assemblages requires the loss of anatectic melt to preserve high-temperature minerals such as garnet and orthopyroxene (e.g. Spear et al. 1999; White and Powell 2002). 
(a)

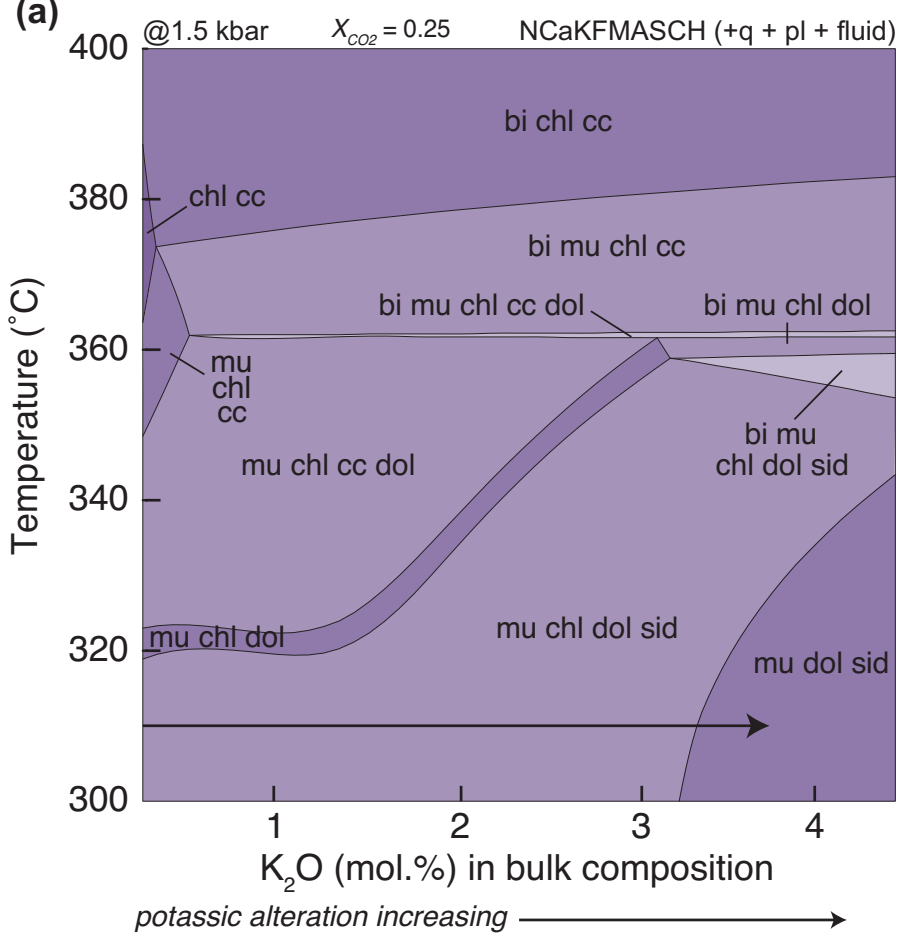

(b)

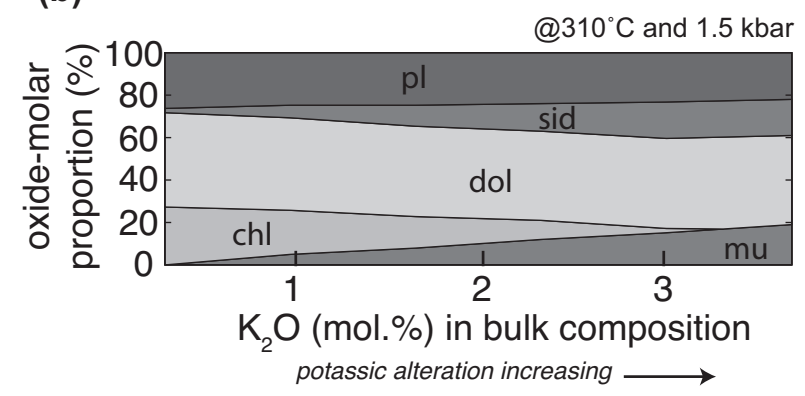

Figure 6. An example of phase equilibria modelling applied to alteration associated with gold mineralization. (a) Temperature-Composition (Alteration) phase diagram calculated at $1.5 \mathrm{kbar}$ for a metabasite (modified from White et al. 2003). The horizontal axis represents an increasing intensity of potassic alteration towards the righthand side of the diagram. The left-hand side of the diagram represents an approximate protolith composition. (b) An isothermal $\left(310^{\circ} \mathrm{C}\right)$ and isobaric $(1.5 \mathrm{kbar})$ Composition-Mode diagram showing the change in the proportion of phases with increasing potassic alteration. Note that the amounts of muscovite and siderite increase at the expense of chlorite, plagioclase and dolomite. Excess quartz and fluid $\left(\mathrm{X}_{\mathrm{CO} 2}=\right.$ 0.25 ) are assumed for both diagrams.

If melt stayed in the system, high-temperature minerals are expected to retrogress to lower-temperature minerals during cooling and melt crystallization. Because phase equilibria modelling predicts the composition and mode of melt at $P-T$, a specified amount of melt can be subtracted out of the bulk composition leaving behind a more residual composition. This has implications for quantification of the amount of melt extracted from a system, determination of the change(s) in the rheological behaviour (e.g. strength) of migmatite during prograde metamorphism and evaluation of the tectonic processes that operate in the anatectic crust.

Yakymchuk and Brown (2014a) modelled the changes in the fertility (i.e. amount of melt that can be produced during anatexis) and density of a metapelite during a metamorphic evolution with periodic melt drainage events. These authors assumed that melt drains from the system when the proportion of melt reached a critical threshold. This critical value was set at $7 \%$ melt, which is a rheological threshold where melt is assumed to form an interconnected network along grain boundaries (e.g. Rosenberg and Handy 2005) that allows melt drainage out of the system. Yakymchuk and Brown (2014a) assumed that when the melt proportion reached the $7 \%$ threshold, $6 \%$ melt was drained from the system, which leaves $1 \%$ in the system. However, this exercise can easily be done for different melt thresholds including quasi-continuous melt extraction, which may be applicable to migmatites with high melt fractions undergoing syn-anatectic deformation (e.g. Vigneresse and Burg 2000). Figure 7a shows Temperature-Mode diagrams calculated for closed system (undrained) and open system (drained) metamorphism along an isobaric heating path at $12 \mathrm{kbar}$. Note that the changes in mineral modes are roughly equivalent up-temperature between the two scenarios. One notable exception is that the proportion of melt produced in an open system $(30 \%)$ is less than the amount generated in a closed system (36\%). The effect of melt drainage on the reduced ability of the rock to generate additional melt is even more significant for decompression $P-T$ paths (cf. Yakymchuk and Brown 2014a).

The effect of anatexis and melt drainage on rock density for an isothermal decompression path at $820^{\circ} \mathrm{C}$ for the same metapelite is shown in Figure 7b. The density of the migmatite (e.g. the density of the residue plus any melt in the system) is compared with the density of the immediately overlying subsolidus crust for the same protolith composition. Similar to the isobaric heating path, melt loss events are labelled on the diagram at the $7 \%$ melt threshold. During decompression from $12 \mathrm{kbar}$ the migmatite is of equivalent or greater density to the overlying subsolidus crust until $\sim 6 \mathrm{kbar}$. At this pressure, biotite and sillimanite break down to produce cordierite, which is a relatively low-density mineral. This causes the density of the migmatite to decrease to values below that of the overlying crust during further decompression, which creates a buoyancy contrast. The positive buoyancy of the migmatite relative to the overlying crust may be a mechanism that enhances the exhumation of migmatite gneiss domes and metamorphic core complexes (e.g. Whitney et al. 2013).

Mayne et al. (2016) developed an algorithm that models the same open-system melting scenario as Yakymchuk and Brown (2014a), but for a much larger number of $P-T$ paths. The conclusions of Mayne et al. (2016) were the same as Yakymchuk and Brown (2014a), although their new algorithm can be applied to numerous other path-dependent open-system processes.

\section{Deformation and Tectonics}

Partial melting has significant implications for the rheology of the deep crust. The decrease in strength of the crust during anatexis is well established for closed systems (e.g. Rosenberg and Handy 2005), but the consequences of melt extraction on the strength of the remaining residuum in the deep crust are 
(a)

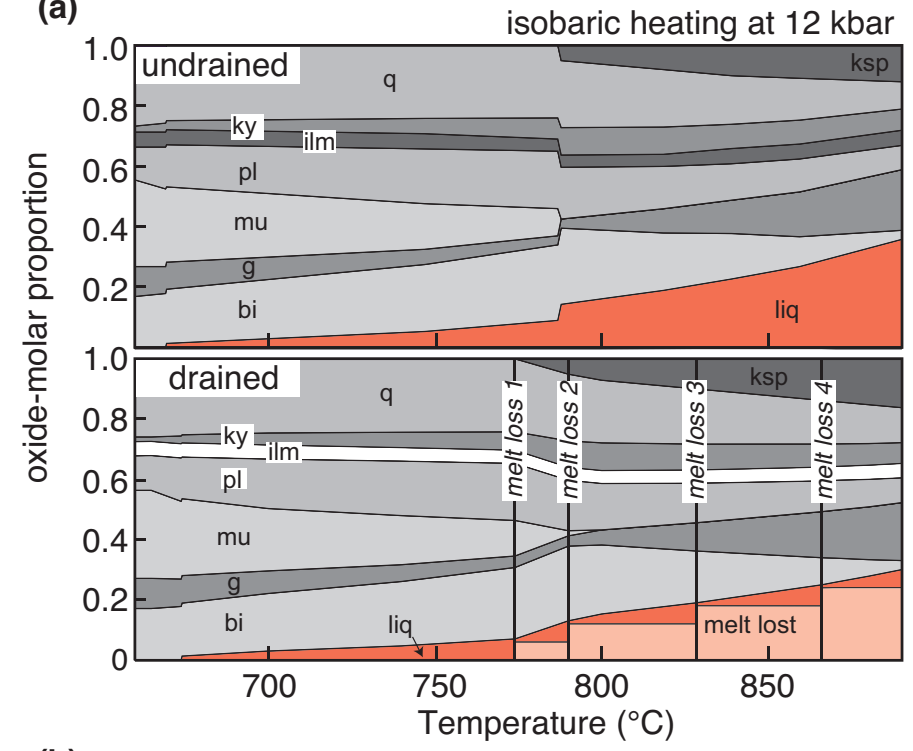

(b)

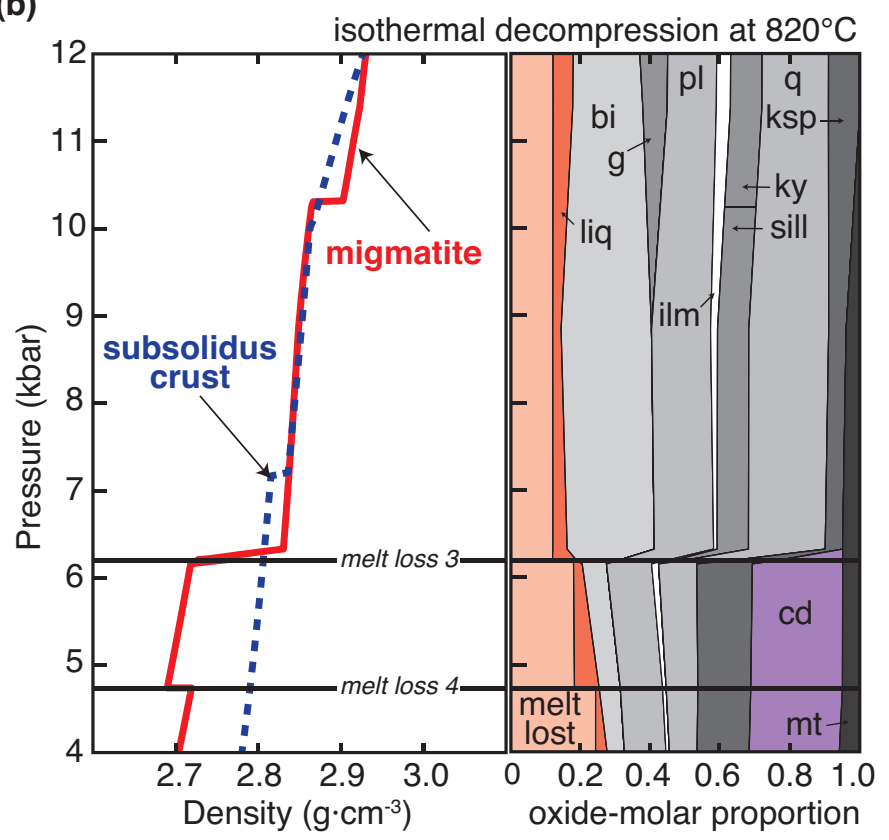

Figure 7. An example of phase equilibria modelling applied to open system behaviour and melt loss during high-temperature metamorphism (modified from Yakymchuk and Brown 2014a). (a) Temperature-mode diagrams for isobaric heating at 12 kbar for an average amphibolite-facies metapelite. Two scenarios are shown: a closed system (undrained) where all of the melt produced remains in the rock and an open system (drained) where melt is periodically extracted at each 'melt loss' event resulting in a more residual composition for the next segment of the heating path. Note that the amount of melt generated in the open system is less. (b) Pressure-Mode diagrams and density evolution curves (relative to subsolidus crust) for isothermal decompression of the same rock and the change in density of the modelled rock. Note the large density decrease during the growth of cordierite. The result is a migmatite that is less dense than the overlying (subsolidus) crust.

not as well understood. This issue has important implications for stabilizing the deep crust during orogenesis and cratonization.

Diener and Fagereng (2014) combined the results of phase equilibria modelling with equations for plastic flow of rocks and minerals to quantify the strength of migmatite during par-
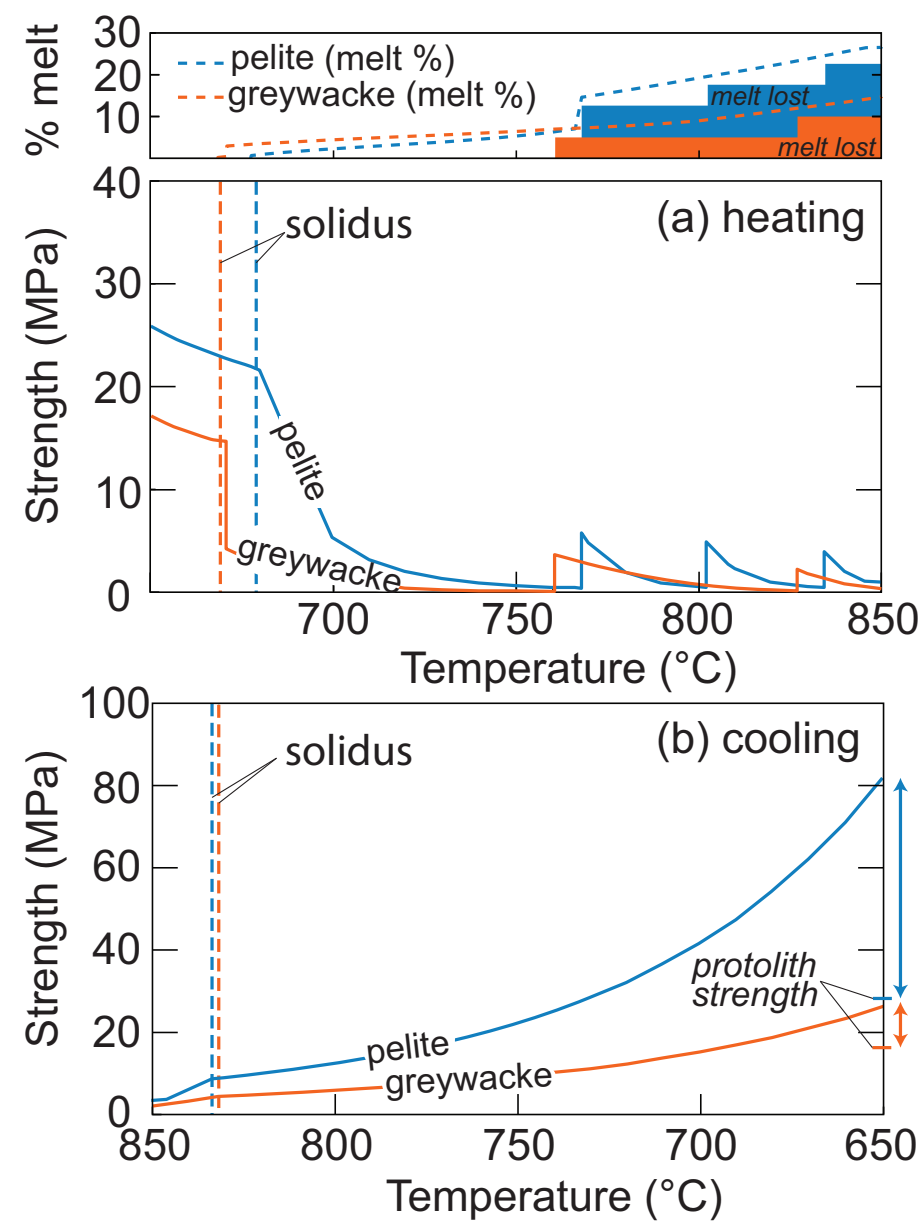

Figure 8. An example of phase equilibria modelling applied to the strength of the crust (modified from Diener and Fagereng 2014). (a) Strength evolution curves for a pelite and greywacke during heating and partial melting at $10 \mathrm{kbar}$. The episodic strength increases are from the extraction of melt from the system at various temperatures. (b) Strength profiles for the same rock types at the same pressure during cooling. Note that the strength of both rocks is much greater than for the same rocks prior to high-temperature metamorphism and melt loss (see arrows on right hand side of diagram).

tial melting and melt extraction. They evaluated the phases and modes in the melt-bearing part of the migmatite (leucosome) and the residual material after melt extraction (residuum, restite or melanosome). This information was combined with rheological models of plastic deformation to quantify the strength of different parts of the migmatite along $P-T$ paths for a metapelite and a greywacke, which generally represent the most fertile rock types in orogenic systems.

The results of their modelling are summarized in Figure 8. There is a non-linear change in the expected strength of the metapelite and metagreywacke during heating and cooling. During heating, the strength of both rock types is predicted to decrease significantly after crossing the solidus and minor punctuated strength increases are expected during punctuated melt extraction episodes (Fig. 8a). For both rock types, the strength decreases by nearly an order of magnitude from the solidus to the peak of metamorphism at $850^{\circ} \mathrm{C}$. During cooling and melt crystallization, the melt-depleted residuum can become up to $400 \%$ stronger than the unmelted protoliths 
(Fig. 8b) - mainly due to the prograde replacement of relatively weak quartz and mica by relatively strong feldspar and garnet-resulting in a dry and strong deep crust. Ultimately, anatectic reworking of the continental crust can lead to cratonization, which then serves as a locus for arc development and accretionary orogens. The study by Diener and Fagereng (2014) provides the first attempt to quantitatively link phase equilibria modelling with crustal rheology and future studies should aim to include intermediate to mafic rocks.

\section{Mantle Rocks}

A relatively recent development in phase equilibria modelling is the compilation of an internally consistent database and solution models for phases in ultrabasic compositions that apply to mantle petrology (e.g. Stixrude and Lithgow-Bertelloni 2005, 2011; Holland et al. 2013; Jennings and Holland 2015). The use of phase equilibria modelling to predict phase assemblages in the deep mantle is a complementary technique to time-consuming high-pressure experiments that are usually conducted in relatively simple chemical systems (e.g. $\mathrm{MgO}-$ $\mathrm{FeO}-\mathrm{SiO}_{2}$; Ito et al. 1984).

Holland et al. (2013) modelled several bulk compositions to evaluate the main phase transitions that occur from the upper mantle through the transition zone to the uppermost lower mantle. This modelling was conducted in the NCFMAS system, which ignores ferric iron and chromium. The main mineral stabilities calculated from their modelling for a representative peridotite composition are summarized in Figure 9a. A mantle geotherm from Stixrude and Lithgow-Bertelloni (2007) is shown in Figure 9a and a Pressure-Mode diagram along this geotherm is shown in Figure 9b. There are several transitions that occur along the geotherm, but most striking is the appearance of $\mathrm{MgSi}$-perovskite and ferropericlase at a depth of $\sim 660$ $\mathrm{km}$, which generally corresponds to current interpretations of the depth of the transition zone between the upper and lower mantle.

Jennings and Holland (2015) expanded the NCFMAS system to include ferric iron and chromium for pressures up to 60 kbar. An important implication of their work is that the mantle oxidation state depends on $P, T$ and the phase assemblage and the oxidation state varies in a complex way for a single phase assemblage. This chemical system can also be used to investigate the phase transitions in the non-hydrous components of subducting lithospheric slabs.

While these studies are preliminary, they are some of the first applications of phase equilibria modelling to mantle petrology and have the potential to allow the phase relations to be evaluated for a wide variety of compositions. Experimental data are still limited for some deep mantle phases and complex solution models that contain $\mathrm{K}$ and Ti have not yet been developed. Nonetheless, phase equilibria modelling of ultrabasic compositions at mantle conditions is an evolving field and studies that link the development and testing of these models with observations from geophysical studies of the deep Earth are a fruitful avenue for further research.

\section{Geochemical Cycles and Subduction Zones}

The depths and temperatures of fluid production in down-

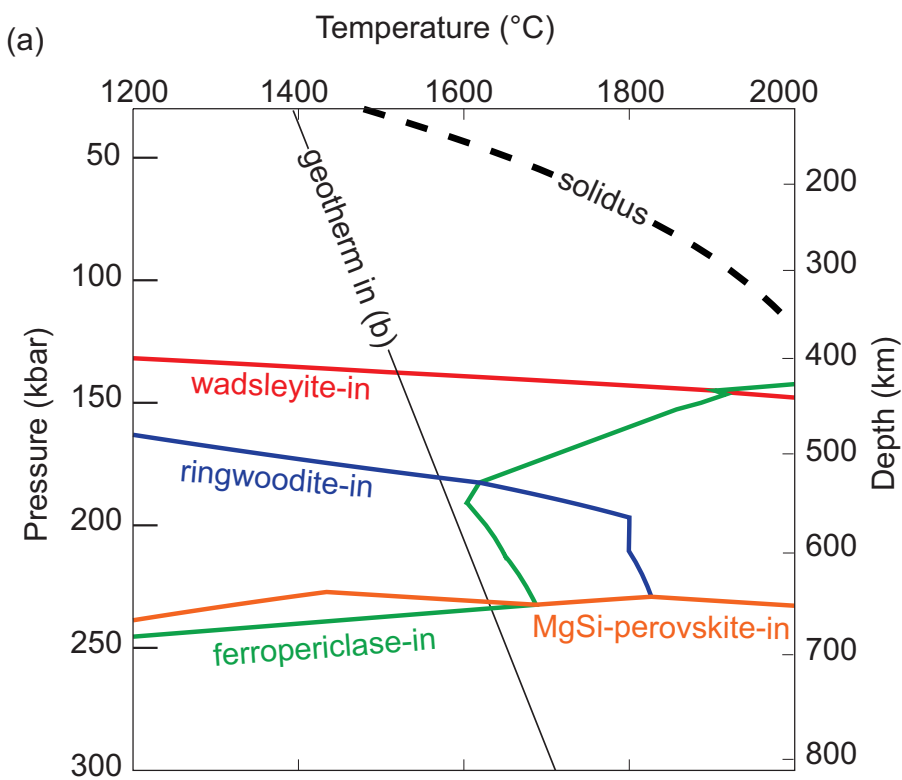

(b)

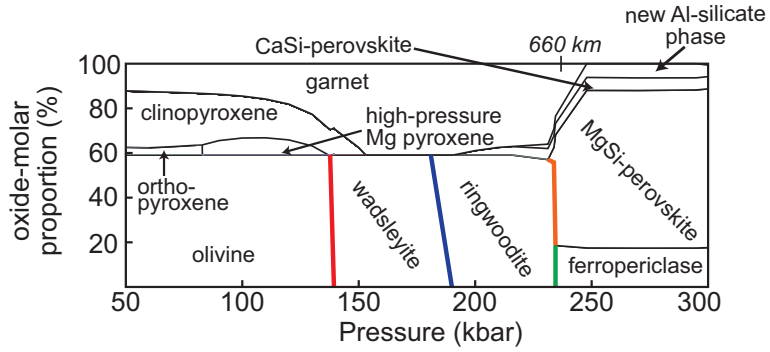

Figure 9. Phase equilibria modelling applied to deep mantle assemblages. (a) Pressure-Temperature phase diagram illustrating the main mineral-in reactions applicable to mantle rocks (modified from Holland et al. 2013). Note that pressure increases towards the bottom of the diagram. (b) Pressure-Mode diagram showing the proportions of the different minerals along the geothermal gradient in (a) (modified from Holland et al. 2013). An important link to geophysical studies is the breakdown of ringwoodite to $\mathrm{MgSi}$-perovskite (and other phases) that roughly coincides with a depth of $\sim 660 \mathrm{~km}$.

going slabs have important implications for subduction-related earthquakes, geochemical cycling of carbon and the generation of arc-related magmas and mineral deposits. The fluids released during metamorphism of the subducted crust and lithospheric mantle can be investigated with phase equilibria modelling. Evans and Powell (2015) modelled the change in phase assemblages, modes, and compositions for a metasomatized ultramafic rock along two geothermal gradients appropriate for different tectonic settings. A selection of their results for a cold geothermal gradient is shown in Figure 10.

The Temperature-Mode diagram in Figure 10a displays three main phase transitions along the geotherm: (1) pyrrhotite breaks down to produce pyrite at $\sim 430^{\circ} \mathrm{C}$, (2) brucite reacts out to olivine and fluid at $\sim 520^{\circ} \mathrm{C}$, and (3) antigorite breaks down to olivine, orthopyroxene, trace amounts of chlorite and fluid from $520^{\circ} \mathrm{C}$ to $570^{\circ} \mathrm{C}$. The breakdown of antigorite generates a large quantity of fluid. The transition from pyrrhotite to pyrite does not change the $\mathrm{H}_{2} \mathrm{~S}$ composition of the fluid significantly and the $\mathrm{H}_{2} \mathrm{~S}$ proportion in the fluid phase remains low (Fig. 10b). The modelling of Evans and Powell (2015) also 


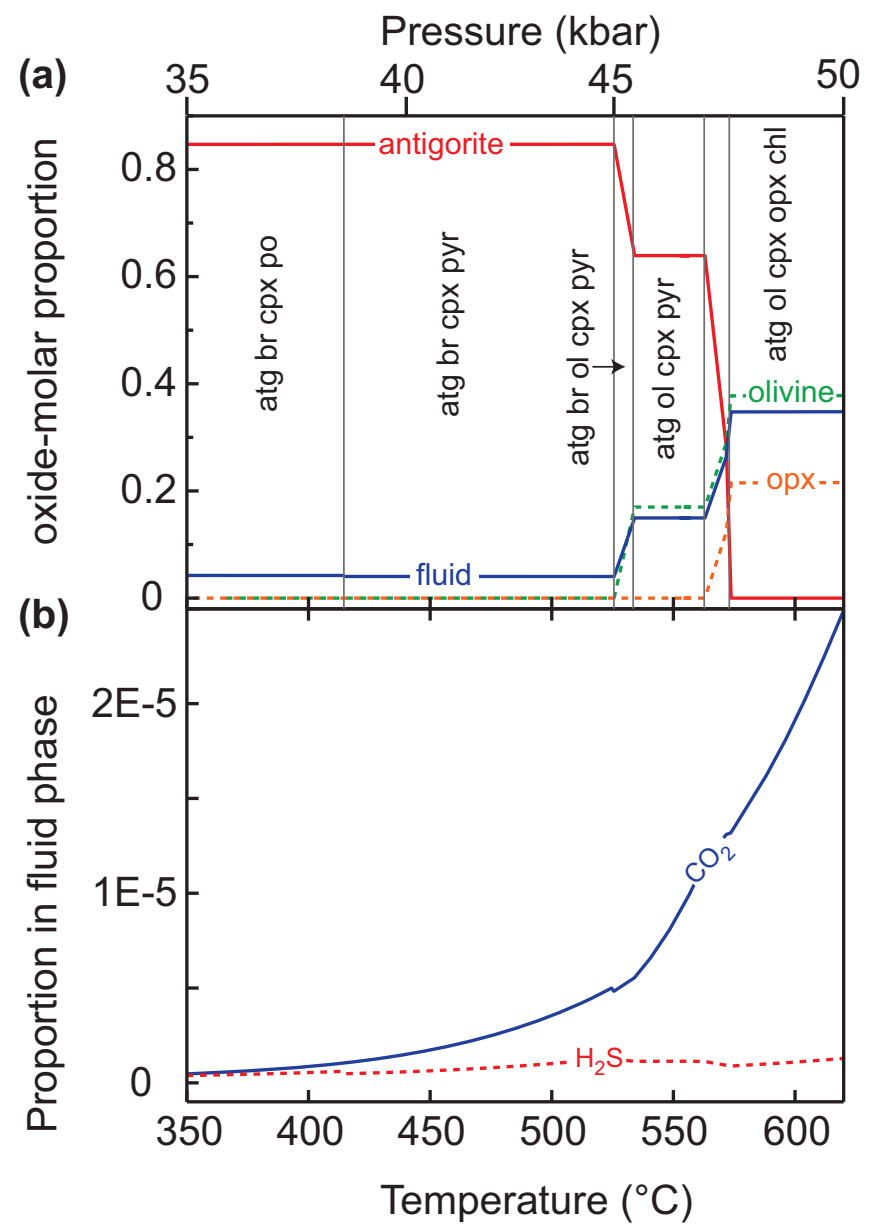

Figure 10. An example of phase equilibria modelling applied to fluid generation from a hydrated ultramafic rock during subduction (modified from Evans and Powell 2015). Note that magnesian carbonate and magnetite are in excess. (a) Temperature-Mode diagram for a relatively cold geothermal gradient. The important fluidproducing reactions involve the breakdown of antigorite and brucite to olivine at temperatures $>525^{\circ} \mathrm{C}$. (b) Concentration of $\mathrm{CO}_{2}$ and $\mathrm{H}_{2} \mathrm{~S}$ in the fluid phase along the same geotherm.

suggests that most sulphur will be transported to the deep mantle and relatively little is recycled back to the surface in arc magmas. Nonetheless, the $\mathrm{H}_{2} \mathrm{~S}$ that does make it into an arc system may act as a ligand to transport and ultimately act to concentrate elements of economic interest, especially precious metals, in magmatic-hydrothermal mineral deposits.

Although pyrrhotite breakdown is modelled to occur at $\sim 430^{\circ} \mathrm{C}$ along the modelled geothermal gradient, the temperature of pyrrhotite breakdown is sensitive to other factors such as closed versus open system behaviour and redox state, which are explored in more detail by Evans and Powell (2015). A broader implication of this type of modelling is that the breakdown of pyrrhotite may also liberate trapped platinum group elements into the fluid (and/or melt) phase, which has implications for the generation of Ni-PGE deposits as well as for Re-Os geochronology of mantle samples.

Figure 10 shows that the concentration of $\mathrm{CO}_{2}$ in the fluid is predicted to increase during prograde metamorphism in a subduction setting. A prediction of the modelling by Evans and Powell (2015) is that $<5 \%$ of the $\mathrm{CO}_{2}$ in the rock will enter the fluid phase. The remainder is subducted into the deep mantle where it may influence mantle-melting reactions. While phase equilibria modelling of $\mathrm{C}-\mathrm{O}-\mathrm{H}-\mathrm{S}$ fluids in the mantle is still relatively underexplored, it represents an opportunity to link the predictions of phase equilibria modelling with measurements of mantle xenoliths and experimental studies to better understand the geochemical cycling of carbon and sulphur as well as diamond growth in the lithospheric mantle.

\section{Earthquakes}

Changes in rock strength during metamorphism and metasomatism in subduction and collisional tectonic settingsincluding implications for earthquake localization-can be evaluated with phase equilibria modelling (e.g. Fagereng and Diener 2011; Getsinger et al. 2013). Fagereng and Diener (2011) used phase equilibria modelling to investigate prograde and retrograde reactions of rocks from the Franciscan Complex at the depths and temperatures thought to be appropriate for seismicity related to the San Andreas 'tectonic tremor.' They suggested that mantle-derived fluids may induce retrograde metamorphism of mafic rocks and greywacke leading to the production of abundant phyllosilicate minerals that result in fault-zone weakening and localization.

Getsinger et al. (2013) combined microstructural constraints with phase equilibria modelling of water activity in mafic rocks to understand how mineralogical changes in response to fluid infiltration affect the rheology of the lower crust. They showed that deformation in the lower crust is strongly partitioned into relatively narrow fluid-altered zones leaving the bulk of the lower crust relatively strong. This has implications for how the lower crust responds to tectonic stresses and the localization of low-frequency earthquakes.

\section{Climate Change}

Metamorphic fluid compositions can be predicted through phase equilibria modelling for a variety of geological settings, which has implications for the geochemical cycles of carbon and sulphur and the generation of greenhouse gases in metamorphic settings (Aarnes et al. 2010; Skora et al. 2015; Tomkins and Evans 2015). Aarnes et al. (2010) evaluated the composition and volumes of metamorphic fluids produced through contact metamorphism of organic-rich metasedimentary rocks. These authors calculated that basin-scale contact metamorphism could have generated up to $~ 16,200 \mathrm{Gt}$ of thermogenic $\mathrm{CH}_{4}$ in the Karoo Basin (South Africa) within 10-1000 years. This quantity of $\mathrm{CH}_{4}$ was predicted to produce a global $\delta^{13} \mathrm{C}$ excursion of -3 to $-5 \%$. Aarnes et al. (2010) proposed a link between large igneous provinces, contact metamorphism of organic-rich sedimentary rocks, global warming and mass extinction in the Toarcian stage of the Lower Jurassic.

\section{Meteorites}

Phase equilibria modelling can also be applied to extraterrestrial rocks to evaluate how parental asteroid bodies are constructed. Johnson et al. (2016) modelled metamorphism of three 
groups of ordinary chondrite compositions. A $P-T$ isochemical phase diagram for an average of the 'LL' group of ordinary chondrites is shown in Figure 11. Note that garnet is restricted to $P>10 \mathrm{kbar}$ and plagioclase is stable at $P<9-15 \mathrm{kbar}$ with increasing temperature. Considering that nearly all ordinary chondrites are thought to record metamorphic conditions at pressures $<1 \mathrm{kbar}$, the results of Johnson et al. (2016) are consistent with the observation that most, or all, ordinary chondrites contain plagioclase and lack garnet. While the model results of Johnson et al. (2016) are preliminary, their study opens the door for further work to evaluate how oxidation affects chondrite mineralogy (e.g. McSween and Labotka 1993), the effects of melt loss on the chemical differentiation of planetesimals and the 'onion-shell' versus 'rubble-pile' hypotheses of the parent asteroids of ordinary chondrites (e.g. Harrison and Grimm 2010).

\section{Accessory Minerals}

Accessory minerals make up a small proportion of most rocks, but they are disproportionately large repositories of trace elements. Furthermore, many accessory minerals contain suitable quantities of $\mathrm{U}$ and $\mathrm{Th}$ to be dated through $\mathrm{U}-\mathrm{Pb}$ geochronology. The behaviour of some accessory minerals used in metamorphic studies such as epidote and titanite as well as oxides (e.g. rutile, ilmenite) and sulphides can be quantified for different bulk compositions and $P-T$ conditions using phase equilibria modelling (e.g. White et al. 2007; Evans et al. 2010; Palin et al. 2016b). However, the behaviour of the most commonly used $\mathrm{U}-\mathrm{Pb}$ chronometers (zircon and monazite) are more difficult to quantify with current phase equilibria modelling techniques (e.g. Spear and Pyle 2010; Kelsey and Powell 2011). This is because some of their essential structural constituents ( $\mathrm{Zr}$, P, LREE) are not usually considered in model chemical systems.

For subsolidus metamorphic rocks, accessory minerals can be produced through solid-state reactions (Rubatto et al. 2001; Wing et al. 2003) and may also precipitate from fluids (Ayers et al. 1999; Schaltegger 2007). Zircon is generally expected to be unreactive or consumed during subsolidus metamorphism (e.g. Kohn et al. 2015), whereas monazite is generally more reactive and can be used to date particular portions of subsolidus $P-T$ paths. Phase equilibria modelling of subsolidus monazite behaviour is restricted to relatively few studies (Spear 2010; Spear and Pyle 2010). Spear and Pyle (2010) compiled a thermodynamic database that included apatite, monazite and xenotime and they were the first to develop a $P-T$ isochemical phase diagram that includes phosphates. Spear (2010) used phase equilibria modelling to show that the temperature of allanite breakdown to monazite is sensitive to bulk rock concentrations of calcium and aluminum. Both of these studies have implications for interpreting the reaction sequence of monazite growth in metapelitic rocks and the geological significance of monazite $\mathrm{U}-\mathrm{Pb}$ ages.

For suprasolidus rocks, accessory mineral behaviour is strongly linked with the amount and composition of anatectic melt in the system. Because the composition and mode of melt in a metamorphic system can be predicted with phase

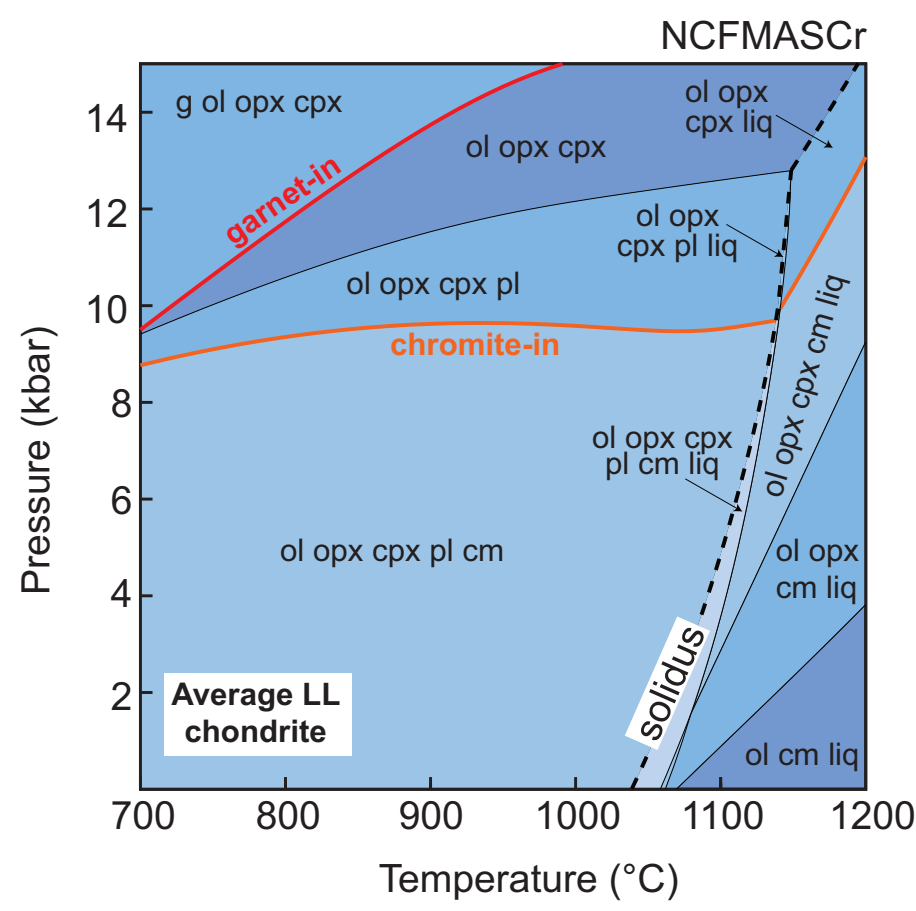

Figure 11. A Pressure-Temperature phase diagram for a LL ordinary chondrite (modified from Johnson et al. 2016). The modelling does not predict garnet at pressures $<9 \mathrm{kbar}$, which is consistent with the absence of garnet from LL ordinary chondrites and the hypothesis that most were metamorphosed in a parent body at $P<1$ kbar.

equilibria modelling, this information can be combined with solubility equations of accessory minerals (determined from experimental studies) to evaluate when these minerals are expected to grow and be consumed along a metamorphic $P-T$ path (e.g. Kelsey et al. 2008; Spear and Pyle 2010; Kelsey and Powell 2011; Yakymchuk and Brown 2014b; Kohn et al. 2015; Yakymchuk et al. 2017; Yakymchuk 2017).

Kelsey et al. (2008) combined zircon and monazite solubility equations with the mode and composition of anatectic melt predicted for pelite and greywacke compositions to determine the amount of accessory mineral dissolution for a wide range of suprasolidus $P-T$ conditions. Their study was followed by the development of solution models for Zr-bearing silicate melt and garnet that allowed quantitative phase equilibria modelling of suprasolidus zircon behaviour (Kelsey and Powell 2011). Further experimental work on zircon and monazite solubility (Stepanov et al. 2012; Boehnke et al. 2013) refined the solubility equations for these minerals. Yakymchuk and Brown (2014b) used these revised solubility equations to evaluate the effects of open-system behaviour on the stability of monazite and zircon.

An example of the behaviour of zircon and monazite in suprasolidus rocks from Yakymchuk et al. (2017) is shown in Figure 12. Figure 12a is a Temperature-Composition $(T-X)$ phase diagram that shows the phase assemblages and melt proportion isopleths for compositions ranging linearly from an average metapelite (left side) to an average passive margin greywacke (right side). Figure $12 \mathrm{~b}$ and $12 \mathrm{c}$ show the percentage of zircon and monazite dissolution (relative to the amount 
(a)

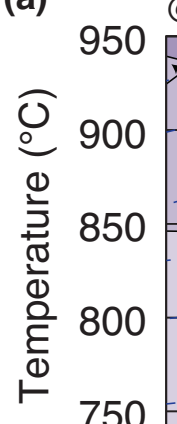

@ 7 kbar

MnNCKFMASHTO (+ pl + ilm)
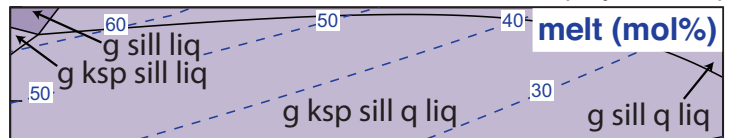

30
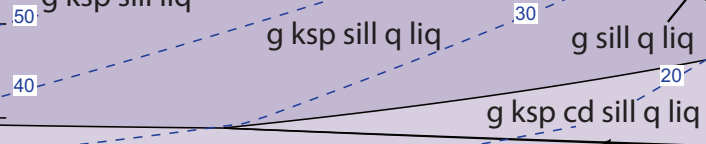

$-30--$

ksp cd sill q liq

$\mathrm{g}$ bi ksp sill q liq

g bi ksp cd sill q liq _. 10

(b)
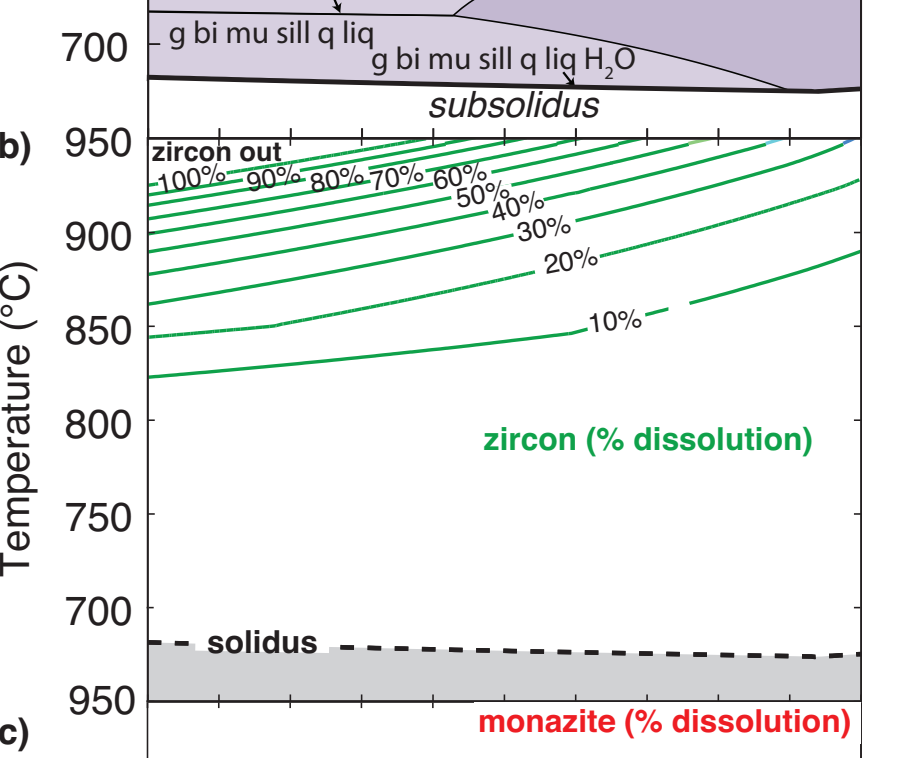

(c)

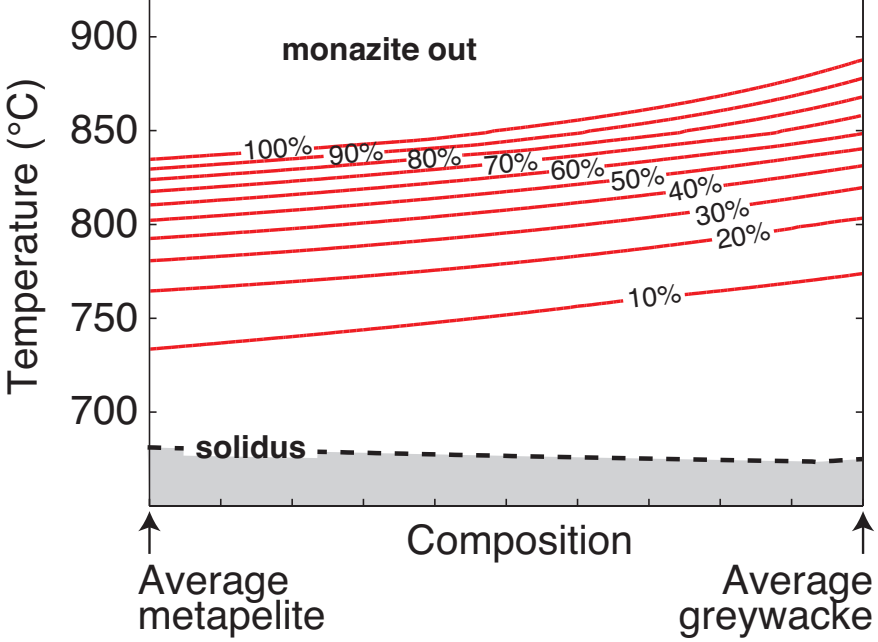

Figure 12. Temperature-Composition diagrams exploring the behaviour of zircon and monazite during partial melting for compositions ranging linearly between an average metapelite at the left side of the diagram and an average greywacke at right side of the diagram in a closed system with no melt loss (modified from Yakymchuk et al. 2017). (a) Phase diagram showing the change in melt mode (mol.\%) and phase assemblages across the modelled compositional range. (b) Contours for the amount of zircon dissolution (\%) relative to the amount existing at the solidus. Note that zircon is predicted to be completely consumed at $930^{\circ} \mathrm{C}$ for a pelite and only $20 \%$ of zircon is expected to be consumed for the greywacke. (c) Contours for the amount of monazite dissolution (\%) relative to the amount existing at the solidus. Monazite dissolution is less sensitive to changing bulk composition than zircon and monazite is expected to be completely consumed in both rock types by $900^{\circ} \mathrm{C}$. present at the solidus) required to maintain zirconium and light rare earth element (LREE) saturation of the anatectic melt, respectively. The calculations are conducted for specific bulk rock compositions of zirconium and the LREE. In this case, both are assumed to be $150 \mathrm{ppm}$, which is interpreted to represent a reasonable value for most pelites and greywackes and their high-grade equivalents (e.g. Yakymchuk and Brown 2014b).

Dissolution contours have negative slopes on Figure $12 \mathrm{~b}$ and $12 \mathrm{c}$ and the spacing between contours decreases up temperature. The negative slopes indicate that, at a given temperature, the amounts of zircon and monazite dissolution are greater for the metapelite composition (left-hand side of the diagram) than for the greywacke composition (right-hand side of the diagram). The main controlling factor for the difference between the two rocks is that the metapelite is predicted to generate more melt at a given $T$ than the greywacke. Therefore, proportionally more zircon and monazite dissolution are required to maintain melt saturation with respect to these minerals for the pelite. The closer spacing of the contours at high temperatures suggests that the amount of zircon and monazite dissolution is non-linear with temperature. This is a function of the rate of melt production and the increased solubility of the accessory minerals at high temperatures.

For the metapelite, zircon is expected to be completely consumed (i.e. $100 \%$ contours in Fig. $12 \mathrm{~b}$, c) by $\sim 930^{\circ} \mathrm{C}$ (lefthand side of the diagram) and monazite is exhausted by $\sim 840^{\circ} \mathrm{C}$ (left-hand side of the diagram). For the greywacke, some zircon is expected to survive up to $950^{\circ} \mathrm{C}$ and monazite is expected to be completely consumed by $880^{\circ} \mathrm{C}$. Conversely, melt crystallization during cooling is predicted to result in new zircon and monazite growth. The assumptions and limitations of an equilibrium approach to modelling accessory mineral behaviour in metamorphic rocks are discussed elsewhere (Kelsey et al. 2008; Yakymchuk and Brown 2014b; Yakymchuk et al. 2017). In particular, these models do not consider phosphorus, which has important implications for the stability of monazite (and apatite) in melt (e.g. Duc-Tin and Keppler 2015; Yakymchuk 2017).

\section{ASSUMPTIONS AND LIMITATIONS OF PHASE EQUILIBRIA MODELLING}

Like any model, phase equilibria modelling represents a necessary simplification of complex natural systems. There are two main categories of uncertainties when applying equilibrium thermodynamics to metamorphic phase assemblages: systematic uncertainties (Powell 1985) and random uncertainties (Palin et al. 2016a). The first are the systematic uncertainties in the thermodynamic properties of phase end-members in thermodynamic databases (Helgeson et al. 1978; Berman 1988; Holland and Powell 2011) and those related to the formulation of activity-composition models (e.g. O'Brien 2008; White et al. 2014a). For example, Pattison and Debuhr (2015) demonstrated that natural phase assemblages in subsolidus cordieritebearing metapelite are reproduced by a modified version of the Berman (1988) database and associated activity-composition models (Pattison et al. 2002; Spear and Pyle 2010), but not 
by the Holland and Powell $(1998,2011)$ databases and associated activity-composition models. The systematic uncertainties of phase equilibria modelling will decrease as more experimental data become available and more natural rock assemblages are examined and integrated into activity-composition models. In some cases, error propagation can be used to assess the uncertainty in $P-T$ estimates (e.g. Powell 1985) and, more recently, Monte Carlo simulations were used to quantify systematic uncertainties (Jennings and Holland 2015; Palin et al. 2016a).

The second category of uncertainties comprises geological uncertainties that are difficult to quantify. These include: (1) choosing an effective bulk composition of a system (e.g. Guevara and Caddick 2016), and (2) evaluating if a phase assemblage is in equilibrium and assessing any kinetic barriers to attaining equilibrium (e.g. Pattison et al. 2011; Spear et al. 2016). Another source of uncertainty is the misidentification of reaction sequences and equilibrium phase assemblages (e.g. Vernon et al. 2008), but this needs to be assessed on a case-bycase basis.

The effective bulk composition of a metamorphic system can change along a $P-T$ evolution. The partitioning of particular cations into growing porphyroblasts (e.g. Mn into garnet) and different diffusion rates for cations can result in growthzoned minerals where the cores are not in equilibrium with the surrounding phase assemblage. In some cases, this can be examined by forward modelling of porphyroblast growth (e.g. Zuluaga et al. 2005; Gaidies et al. 2008; Moynihan and Pattison 2013).

Melt loss during suprasolidus metamorphism produces more residual compositions, elevated solidus temperatures and a greater proportion of peritectic minerals relative to the undrained protolith compositions (e.g. Yakymchuk and Brown 2014a; Guevara and Caddick 2016). While these residual compositions are useful for determining peak $P-T$ and portions of the retrograde path, they may not be appropriate for investigating prograde metamorphic reactions that require an estimate of the effective bulk composition before melt extraction. Inverse modelling has been used to add melt back into the bulk composition while working down temperature (White et al. 2004; Indares et al. 2008; Guilmette et al. 2011), but this requires an assumption of the $P-T$ trajectory of the prograde path, which is not always clear.

Assessing if a metamorphic phase assemblage is in equilibrium is a matter of interpretation and the scale of observation. Most petrologists would interpret high-temperature metamorphic minerals that are compositionally homogeneous with lowenergy grain shapes (e.g. triple junctions at grain boundaries) to represent an equilibrium assemblage. However, very few metamorphic rocks fit these criteria. Reaction microstructures (e.g. coronae around porphyroblasts) may be interpreted by one geologist to record disequilibrium at the scale of a hand sample or thin section and by another to represent equilibrium at the scale of grain boundaries. Therefore, the interpretation comes down to the scale of observation. Equilibrium volumes are anticipated to be larger for high-temperature systems that may permit relatively rapid cation transport, such as through melt along grain boundaries, and smaller for lower-temperature systems where intergranular diffusion rates of cations may be very slow. However, this temperature-related generality may be secondary to the presence and nature of intergranular volatile species (e.g. Carlson et al. 2015a).

Metamorphic reactions may not proceed at the $P-T$ conditions predicted from phase equilibria modelling due to kinetic barriers related to nucleation, interface reaction and intergranular transport (Ridley and Thompson 1986; Rubie 1998; Gaidies et al. 2011; Carlson et al. 2015b). Kinetic barriers to nucleation are generally considered to be the dominant rate-limiting step in metamorphic phase assemblages reaching equilibrium (e.g. Ague and Carlson 2013). Kelly et al. (2013) used numerical modelling of diffusion-controlled nucleation (and growth) of garnet to show that garnet nucleation begins after $5-67^{\circ} \mathrm{C}$ of thermal overstep. Waters and Lovegrove (2002) and Pattison et al. (2011) showed how reaction affinity modelling could be used to predict the degrees of overstepping to be expected for different reactions, the results of which agreed with observations from the Bushveld aureole (Waters and Lovegrove 2002) and Nelson aureole (Pattison and Tinkham 2009). Reaction overstepping and disequilibrium processes are probably more widespread than previously acknowledged and are essential components of a rock's metamorphic history.

All of the limitations discussed above need to be considered when applying the results of phase equilibria modelling to natural metamorphic rocks and in particular to detailed studies of $P-T-t$ paths. Nonetheless, the equilibrium approach to metamorphic assemblages reproduces many first-order observations from metamorphic rocks and this methodology can be applied to various geological questions in a relatively fast and inexpensive way. Thermodynamics and phase equilibrium modelling also provide some of the theoretical tools to evaluate the possible consequences of disequilibrium processes (e.g. Pattison et al. 2011).

\section{CONCLUSIONS AND OUTLOOK}

Phase equilibria modelling has evolved over the last few decades and now allows for a variety of phase diagrams to be calculated with different variables for a wide range of compositions. While there may be limitations to the equilibrium approach to understanding metamorphic rocks and processes, it provides an excellent framework to test and refine hypotheses and opens up connections to many other areas of the geosciences. Linking the predictions of phase equilibria modelling of mantle rocks with observations from geophysical studies is a fruitful avenue for further work. Developing alteration vectors to mineralization using phase diagrams is an underexplored connection to economic geology. Integrating metamorphic phase diagrams into global geochemical cycles from the Archean to the present may provide new insights into the secular change of the lithosphere, hydrosphere and atmosphere. The continual refinement of activity-composition models of different phases and expanding model chemical systems may soon allow a more quantitative method to evaluate accessory mineral behaviour in metamorphic systems. Finally, the interplay between equilibrium and kinetics in the pressure-temper- 
ature-fluid-deformation history of rocks is at an early stage of investigation and will be the focus of much future research.

\section{ACKNOWLEDGEMENTS}

This admittedly biased review has benefited from numerous interactions with colleagues and students. Discussions with M Brown, MJ Caddick, C Clark, DRM Pattison and RW White were particularly insightful. I thank T Rivers and DRM Pattison for very thorough and constructive reviews of this manuscript. I thank Andrew Kerr for the invitation to write this contribution and for his editorial handling. I acknowledge funding from a Natural Sciences and Engineering Council of Canada Discovery Grant.

\section{REFERENCES}

Aarnes, I., Svensen, H., Connolly, J.A.D., and Podladchikov, Y.Y., 2010, How contact metamorphism can trigger global climate changes: Modeling gas generation around igneous sills in sedimentary basins: Geochimica et Cosmochimica Acta, v. 74, p. 7179-7195, https://doi.org/10.1016/j.gca.2010.09.011.

Ague, J.J., 1991, Evidence for major mass transfer and volume strain during regional metamorphism of pelites: Geology, v. 19, p. 855-858, https://doi.org/ 10.1130/0091-7613(1991)019<0855:EFMMTA > 2.3.CO;2.

Ague, J.J., and Carlson, W.D., 2013, Metamorphism as garnet sees it: The kinetics of nucleation and growth, equilibration, and diffusional relaxation: Elements, v. 9, p. 439-445, https://doi.org/10.2113/gselements.9.6.439.

Albee, A.L., 1965, A petrogenetic grid for the Fe-Mg silicates of pelitic schists: American Journal of Science, v. 263, p. 512-536, https://doi.org/ 10.2475/ajs.263.6.512.

Ambrose, T.K., Larson, K.P., Guilmette, C., Cottle, J.M., Buckingham, H., and Rai, S., 2015, Lateral extrusion, underplating, and out-of-sequence thrusting within the Himalayan metamorphic core, Kanchenjunga, Nepal: Lithosphere, v. 7, p. 441-464, https://doi.org/10.1130/L437.1.

Ayers, J.C., Miller, C., Gorisch, B., and Milleman, J., 1999, Textural development of monazite during high-grade metamorphism; hydrothermal growth kinetics, with implications for $\mathrm{U}, \mathrm{Th}-\mathrm{Pb}$ geochronology: American Mineralogist, v. 84, $\mathrm{p}$. 1766-1780, https://doi.org/10.2138/am-1999-11-1206.

Berman, R.G., 1988, Internally-consistent thermodynamic data for minerals in the system $\mathrm{Na}_{2} \mathrm{O}-\mathrm{K}_{2} \mathrm{O}-\mathrm{CaO}-\mathrm{MgO}-\mathrm{FeO}-\mathrm{Fe}_{2} \mathrm{O}_{3}-\mathrm{Al}_{2} \mathrm{O}_{3}-\mathrm{SiO}_{2}-\mathrm{TiO}_{2}-\mathrm{H}_{2} \mathrm{O}-\mathrm{CO}_{2}$. Journal of Petrology, v. 29, p. 445-522, https://doi.org/10.1093/petrology/ 29.2.445.

Boehnke, P., Watson, E.B., Trail, D., Harrison, T.M., and Schmitt, A.K., 2013, Zircon saturation re-revisited: Chemical Geology, v. 351, p. 324-334, https://doi.org/ 10.1016/j.chemgeo.2013.05.028.

Boger, S.D., White, R.W., and Schulte, B., 2012, The importance of iron speciation $\left(\mathrm{Fe}^{+2} / \mathrm{Fe}^{+3}\right)$ in determining mineral assemblages: an example from the high grade aluminous metapelites of southeastern Madagascar: Journal of Metamorphic Geology, v. 30, p. 997-1018, https://doi.org/10.1111/jmg.12001.

Bowen, N.L., 1940, Progressive metamorphism of siliceous limestone and dolomite: The Journal of Geology, v. 48, p. 225-274, https://doi.org/10.1086/624885

Brown, M., 2007, Metamorphic conditions in orogenic belts: A record of secular change: International Geology Review, v. 49, p. 193-234, https://doi.org/ 10.2747/0020-6814.49.3.193.

Brown, M., 2014, The contribution of metamorphic petrology to understanding lithosphere evolution and geodynamics: Geoscience Frontiers, v. 5, p. 553-569, https://doi.org/10.1016/j.gsf.2014.02.005

Carlson, W.D., Hixon, J.D., Garber, J.M., and Bodnar, R.J., 2015a, Controls on metamorphic equilibration: the importance of intergranular solubilities mediated by fluid composition: Journal of Metamorphic Geology, v. 33, p. 123-146, https://doi.org/10.1111/jmg.12113.

Carlson, W.D., Pattison, D.R.M., and Caddick, M.J., 2015b, Beyond the equilibrium paradigm: How consideration of kinetics enhances metamorphic interpretation: American Mineralogist, v. 100, p. 1659-1667, https://doi.org/10.2138/am2015-5097.

Carrington, D.P., and Harley, S.L., 1995, Partial melting and phase relations in highgrade metapelites: an experimental petrogenetic grid in the KFMASH system: Contributions to Mineralogy and Petrology, v. 120, p. 270-291, https://doi.org/10.1007/BF00306508.

Carson, C.J., Clarke, G.L., and Powell, R., 2000, Hydration of eclogite, Pam Peninsula, New Caledonia: Journal of Metamorphic Geology, v. 18, p. 79-90, https://doi.org/10.1046/j.1525-1314.2000.00245.x.

Connolly, J.A.D., and Petrini, K., 2002, An automated strategy for calculation of phase diagram sections and retrieval of rock properties as a function of physical conditions: Journal of Metamorphic Geology, v. 20, p. 697-708, https://doi.org/10.1046/j.1525-1314.2002.00398.x.

de Capitani, C., and Brown, T.H., 1987, The computation of chemical equilibrium in complex systems containing non-ideal solutions: Geochimica et Cosmochimica Acta, v. 51, p. 2639-2652, https://doi.org/10.1016/0016-7037(87)90145-1.

de Capitani, C., and Petrakakis, K., 2010, The computation of equilibrium assemblage diagrams with Theriak/Domino software: American Mineralogist, v. 95, p. 1006-1016, https://doi.org/10.2138/am.2010.3354.

Diener, J.F.A., and Fagereng, $\AA ., 2014$, The influence of melting and melt drainage on crustal rheology during orogenesis: Journal of Geophysical Research, v. 119, p. 6193-6210, https://doi.org/10.1002/2014JB011088.

Dragovic, B., Guevara, V.E., Caddick, M.J., Baxter, E.F., and Kylander-Clark, A.R.C., 2016, A pulse of cryptic granulite-facies metamorphism in the Archean Wyoming Craton revealed by $\mathrm{Sm}-\mathrm{Nd}$ garnet and $\mathrm{U}-\mathrm{Pb}$ monazite geochronology: Precambrian Research, v. 283, p. 24-49, https://doi.org/10.1016/j.precamres.2016.07.010.

Duc-Tin, Q., and Keppler, H., 2015, Monazite and xenotime solubility in granitic melts and the origin of the lanthanide tetrad effect: Contributions to Mineralogy and Petrology, v. 169, Article 8, https://doi.org/10.1007/s00410-014-11009.

Elmer, F.L., Powell, R., White, R.W., and Phillips, G.N., 2007, Timing of gold mineralization relative to the peak of metamorphism at Bronzewing, Western Australia: Economic Geology, v. 102, p. 379-392, https://doi.org/10.2113/gsecongeo.102.3.379

Elmer, F.L., Dugdale, A.L., and Wilson, C.J.L., 2008, Application of mineral equilibria modeling to constrain $T$ and $X_{\mathrm{CO} 2}$ conditions during the evolution of the Magdala gold deposit, Stawell, Victoria, Australia: Mineralium Deposita, v. 43 p. 759-776, https://doi.org/10.1007/s00126-008-0192-4.

England, P.C., and Thompson, A.B., 1984, Pressure-Temperature-Time paths of regional metamorphism I. Heat transfer during the evolution of regions of thickened continental crust: Journal of Petrology, v. 25, p. 894-928, https://doi.org/10.1093/petrology/25.4.894.

Evans, K.A., and Powell, R., 2015, The effect of subduction on the sulphur, carbon and redox budget of lithospheric mantle: Journal of Metamorphic Geology, v. 33, p. 649-670, https://doi.org/10.1111/jmg.12140.

Evans, K.A., Powell, R., and Holland, T.J.B., 2010, Internally consistent data for sulphur-bearing phases and application to the construction of pseudosections for mafic greenschist facies rocks in $\mathrm{Na}_{2} \mathrm{O}-\mathrm{CaO}-\mathrm{K}_{2} \mathrm{O}-\mathrm{FeO}-\mathrm{MgO}-\mathrm{Al}_{2} \mathrm{O}_{3}-\mathrm{SiO}_{2}-$ $\mathrm{CO}_{2}-\mathrm{O}-\mathrm{S}-\mathrm{H}_{2} \mathrm{O}$ : Journal of Metamorphic Geology, v. 28, p. 667-687, https://doi.org/10.1111/j.1525-1314.2010.00890.x.

Evans, K.A., Powell, R., and Frost, B.R., 2013, Using equilibrium thermodynamics in the study of metasomatic alteration, illustrated by an application to serpentinites: Lithos, v. 168-169, p. 67-84, https://doi.org/10.1016/j.lithos. 2013.01.016.

Everett, M.E., 2013, Near-surface applied geophysics: Cambridge University Press, Cambridge, 415 p., https://doi.org/10.1017/CBO9781139088435.

Fagereng, A., and Diener, J.F.A., 2011, San Andreas Fault tremor and retrograde metamorphism: Geophysical Research Letters, v. 38, L23303, https://doi.org/ 10.1029/2011GL049550.

Frey, M., de Capitani, C., and Liou, J.G., 1991, A new petrogenetic grid for low-grade metabasites: Journal of Metamorphic Geology, v. 9, p. 497-509, https://doi.org/10.1111/j.1525-1314.1991.tb00542.x.

Gaidies, F., de Capitani, C., and Abart, R., 2008, THERIA_G: a software program to numerically model prograde garnet growth: Contributions to Mineralogy and Petrology, v. 155, p. 657-671, https://doi.org/10.1007/s00410-007-0263-z.

Gaidies, F., Pattison, D.R.M., and de Capitani, C., 2011, Toward a quantitative model of metamorphic nucleation and growth: Contributions to Mineralogy and Petrology, v. 162, Article 975, https://doi.org/10.1007/s00410-011-0635-2.

Getsinger, A.J., Hirth, G., Stünitz, H., and Goergen, E.T., 2013, Influence of water on rheology and strain localization in the lower continental crust: Geochemistry, Geophysics, Geosystems, v. 14, p. 2247-2264, https://doi.org/10.1002/ ggge. 20148

Green, E.C.R., White, R.W., Diener, J.F.A., Powell, R., Holland, T.J.B., and Palin, R.M., 2016, Activity-composition relations for the calculation of partial melting equilibria in metabasic rocks: Journal of Metamorphic Geology, v. 34, p. 845869, https://doi.org/10.1111/jmg.12211.

Groppo, C., Rolfo, F., Castelli, D., and Connolly, J.A.D., 2013, Metamorphic CO production from calc-silicate rocks via garnet-forming reactions in the CFAS$\mathrm{H}_{2} \mathrm{O}-\mathrm{CO}_{2}$ system: Contributions to Mineralogy and Petrology, v. 166, p. 1655 1675, https://doi.org/10.1007/s00410-013-0947-5.

Guevara, V.E., and Caddick, M.J., 2016, Shooting at a moving target: phase equilibria modelling of high-temperature metamorphism: Journal of Metamorphic Geology, v. 34, p. 209-235, https://doi.org/10.1111/jmg.12179.

Guilmette, C., Indares, A., and Hébert, R., 2011, High-pressure anatectic paragneiss- 
es from the Namche Barwa, Eastern Himalayan Syntaxis: Textural evidence for partial melting, phase equilibria modeling and tectonic implications: Lithos, v. 124, p. 66-81, https://doi.org/10.1016/j.lithos.2010.09.003.

Guiraud, M., and Powell, R., 2006, $P-V-T$ relationships and mineral equilibria in inclusions in minerals: Earth and Planetary Science Letters, v. 244, p. 683-694, https://doi.org/10.1016/j.epsl.2006.02.021

Harrison, K.P., and Grimm, R.E., 2010, Thermal constraints on the early history of the H-chondrite parent body reconsidered: Geochimica et Cosmochimica Acta, v. 74, p. 5410-5423, https://doi.org/10.1016/j.gca.2010.05.034.

Helgeson, H.C., Delany, J.M., Nesbitt, H.W., and Bird, D.K., 1978, Summary and critique of the thermodynamic properties of rock-forming minerals: American Journal of Science, v. 278, p. 1-229.

Hensen, B.J., 1971, Theoretical phase relations involving cordierite and garnet in the system $\mathrm{MgO}-\mathrm{FeO}-\mathrm{Al}_{2} \mathrm{O}_{3}-\mathrm{SiO}_{2}$ : Contributions to Mineralogy and Petrology, v. 33, p. 191-214, https://doi.org/10.1007/BF00374063

Holland, T.J.B., and Powell, R., 1998, An internally consistent thermodynamic data set for phases of petrological interest: Journal of Metamorphic Geology, v. 16 p. 309-343, https://doi.org/10.1111/j.1525-1314.1998.00140.x.

Holland, T.J.B., and Powell, R., 2011, An improved and extended internally consistent thermodynamic dataset for phases of petrological interest, involving a new equation of state for solids: Journal of Metamorphic Geology, v. 29, p. 333 383, https://doi.org/10.1111/j.1525-1314.2010.00923.x.

Holland, T.J.B., Hudson, N.F.C., Powell, R., and Harte, B., 2013, New thermodynamic models and calculated phase equilibria in NCFMAS for basic and ultrabasic compositions through the transition zone into the uppermost lower mantle: Journal of Petrology, v. 54, p. 1901-1920, https://doi.org/10.1093/petrology/ egt035.

Indares, A., and Martignole, J., 1985, Biotite-garnet geothermometry in granulitefacies rocks; evaluation of equilibrium criteria: The Canadian Mineralogist, v 23, p. 187-193.

Indares, A., White, R.W., and Powell, R., 2008, Phase equilibria modelling of kyanite-bearing anatectic paragneisses from the central Grenville Province: Journal of Metamorphic Geology, v. 26, p. 815-836, https://doi.org/10.1111/j.15251314.2008.00788.x.

Ito, E., Takahashi, E., and Matsui, Y., 1984, The mineralogy and chemistry of the lower mantle: an implication of the ultrahigh-pressure phase relations in the system $\mathrm{MgO}-\mathrm{FeO}-\mathrm{SiO}_{2}$ : Earth and Planetary Science Letters, v. 67, p. 238-248, https://doi.org/10.1016/0012-821X(84)90119-5.

Jamieson, R.A., Beaumont, C., Hamilton, J., and Fullsack, P., 1996, Tectonic assembly of inverted metamorphic sequences: Geology, v. 24, p. 839-842, https://doi.org/10.1130/0091-7613(1996)024<0839:TAOIMS>2.3.CO;2.

Jamieson, R.A., Beaumont, C., Fullsack, P., and Lee, B., 1998, Barrovian regiona metamorphism: where's the heat?, in Treloar, P.J., and O'Brien, P.J., eds., What Drives Metamorphism and Metamorphic Reactions?: Geological Society, London, Special Publications, v. 138, p. 23-51, https://doi.org/10.1144/ GSL.SP.1996.138.01.03

Jamieson, R.A., Beaumont, C., Medvedev, S., and Nguyen, M.H., 2004, Crustal channel flows: 2. Numerical models with implications for metamorphism in the Himalayan-Tibetan orogen: Journal of Geophysical Research, v. 109, B06407, https://doi.org/10.1029/2003JB002811.

Jamieson, R.A., Beaumont, C., Warren, C.J., and Nguyen, M.H., 2010, The Grenville Orogen explained? Applications and limitations of integrating numerical mod els with geological and geophysical data: Canadian Journal of Earth Sciences, v. 47, p. 517-539, https://doi.org/10.1139/E09-070.

Jeanneret, P., Goncalves, P., Durand, C., Trap, P., Marquer, D., Quirt, D., and Ledru, P., 2016, Tectono-metamorphic evolution of the pre-Athabasca basement within the Wollaston-Mudjatik Transition Zone, Saskatchewan: Canadian Journal of Earth Sciences, v. 53, p. 231-259, https://doi.org/10.1139/cjes-2015-0136.

Jennings, E.S., and Holland, T.J.B., 2015, A simple thermodynamic model for melting of peridotite in the system NCFMASOCr: Journal of Petrology, v. 56, p. 869-892, https://doi.org/10.1093/petrology/egv020.

Johnson, T.E., White, R.W., and Powell, R., 2008, Partial melting of metagreywacke: a calculated mineral equilibria study: Journal of Metamorphic Geology, v. 26, p. 837-853, https://doi.org/10.1111/j.1525-1314.2008.00790.x.

Johnson, T.E., Benedix, G.K., and Bland, P.A., 2016, Metamorphism and partial melting of ordinary chondrites: Calculated phase equilibria: Earth and Planetary Science Letters, v. 433, p. 21-30, https://doi.org/10.1016/j.epsl.2015.10.035.

Kelemen, P.B., and Hirth, G., 2012, Reaction-driven cracking during retrograde metamorphism: Olivine hydration and carbonation: Earth and Planetary Science Letters, v. 345-348, p. 81-89, https://doi.org/10.1016/j.epsl.2012.06.018.

Kelly, E.D., Carlson, W.D., and Ketcham, R.A., 2013, Magnitudes of departures from equilibrium during regional metamorphism of porphyroblastic rocks: Journal of Metamorphic Geology, v. 31, p. 981-1002, https://doi.org/10.1111/ jmg.12053.

Kelsey, D.E., and Hand, M., 2015, On ultrahigh temperature crustal metamorphism: Phase equilibria, trace element thermometry, bulk composition, heat sources, timescales and tectonic settings: Geoscience Frontiers, v. 6, p. 311-356, https://doi.org/10.1016/j.gsf.2014.09.006

Kelsey, D.E., and Powell, R., 2011, Progress in linking accessory mineral growth and breakdown to major mineral evolution in metamorphic rocks: a thermodynamic approach in the $\mathrm{Na}_{2} \mathrm{O}-\mathrm{CaO}-\mathrm{K}_{2} \mathrm{O}-\mathrm{FeO}-\mathrm{MgO}-\mathrm{Al}_{2} \mathrm{O}_{3}-\mathrm{SiO}_{2}-\mathrm{H}_{2} \mathrm{O}-\mathrm{TiO}_{2}-\mathrm{ZrO}$ system: Journal of Metamorphic Geology, v. 29, p. 151-166, https://doi.org/ 10.1111/j.1525-1314.2010.00910.x

Kelsey, D.E., Clark, C., and Hand, M., 2008, Thermobarometric modelling of zircon and monazite growth in melt-bearing systems: examples using model metapelitic and metapsammitic granulites: Journal of Metamorphic Geology, v. 26, p. 199-212, https://doi.org/10.1111/j.1525-1314.2007.00757.x.

Kohn, M.J., and Spear, F., 2000, Retrograde net transfer reaction insurance for pressure-temperature estimates: Geology, v. 28, p. 1127-1130, https://doi.org/ 10.1130/0091-7613(2000)28<1127:RNTRIF>2.0.CO;2.

Kohn, M.J., Corrie, S.L., and Markley, C., 2015, The fall and rise of metamorphic zircon: American Mineralogist, v. 100, p. 897-908, https://doi.org/10.2138/am2015-5064.

Korhonen, F.J., Powell, R., and Stout, J.H., 2012, Stability of sapphirine + quartz in the oxidized rocks of the Wilson Lake terrane, Labrador: calculated equilibria in NCKFMASHTO: Journal of Metamorphic Geology, v. 30, p. 21-36, https://doi.org/10.1111/j.1525-1314.2011.00954.x.

Lasalle, S., and Indares, A., 2014, Anatectic record and contrasting $P-T$ paths of aluminous gneisses from the central Grenville Province: Journal of Metamorphic Geology, v. 32, p. 627-646, https://doi.org/10.1111/jmg.12083.

Mahar, E.M., Baker, J.M., Powell, R., Holland, T.J.B., and Howell, N., 1997, The effect of Mn on mineral stability in metapelites: Journal of Metamorphic Geology, v. 15, p. 223-238, https://doi.org/10.1111/j.1525-1314.1997.00011.x.

Mayne, M.J., Moyen, J.-F., Stevens, G., and Kaislaniemi, L., 2016, Rcrust: a tool for calculating path-dependent open system processes and application to melt loss: Journal of Metamorphic Geology, v. 34, p. 663-682, https://doi.org/ 10.1111/jmg.12199

McSween Jr., H.Y., and Labotka, T.C., 1993, Oxidation during metamorphism of the ordinary chondrites: Geochimica et Cosmochimica Acta, v. 57, p. 1105-1114, https://doi.org/10.1016/0016-7037(93)90044-W.

Morrissey, L.J., Hand, M., Lane, K., Kelsey, D.E., and Dutch, R.A., 2016, Upgrading iron-ore deposits by melt loss during granulite facies metamorphism: Ore Geology Reviews, v. 74, p. 101-121, https://doi.org/10.1016/j.oregeorev. 2015.11.012.

Mottram, C.M., Warren, C.J., Regis, D., Roberts, N.M.W., Harris, N.B.W., Argles, T.W., and Parrish, R.R., 2014, Developing an inverted Barrovian sequence; insights from monazite petrochronology: Earth and Planetary Science Letters, v. 403, p. 418-431, https://doi.org/10.1016/j.epsl.2014.07.006.

Moynihan, D.P., and Pattison, D.R.M., 2013, An automated method for the calculation of $P-T$ paths from garnet zoning, with application to metapelitic schist from the Kootenay Arc, British Columbia, Canada: Journal of Metamorphic Geology, v. 31, p. 525-548, https://doi.org/10.1111/jmg.12032.

O'Brien, P.J., 2008, Challenges in high-pressure granulite metamorphism in the era of pseudosections: reaction textures, compositional zoning and tectonic interpretation with examples from the Bohemian Massif: Journal of Metamorphic Geology, v. 26, p. 235-251, https://doi.org/10.1111/j.1525-1314.2007.00758.x.

Palin, R.M., Weller, O.M., Waters, D.J., and Dyck, B., 2016a, Quantifying geological uncertainty in metamorphic phase equilibria modelling; a Monte Carlo assessment and implications for tectonic interpretations: Geoscience Frontiers, v. 7 p. 591-607, https://doi.org/10.1016/j.gsf.2015.08.005

Palin, R.M., White, R.W., Green, E.C.R., Diener, J.F.A., Powell, R., and Holland, T.J.B., 2016b, High-grade metamorphism and partial melting of basic and intermediate rocks: Journal of Metamorphic Geology, v. 34, p. 871-892, https://doi.org/10.1111/jmg.12212.

Pattison, D., and Harte, B., 1985, A petrogenetic grid for pelites in the Ballachulish and other Scottish thermal aureoles: Journal of the Geological Society, v. 142, p. 7-28, https://doi.org/10.1144/gsjgs.142.1.0007.

Pattison, D.R.M., and Bégin, N.J., 1994, Zoning patterns in orthopyroxene and garnet in granulites: implications for geothermometry: Journal of Metamorphic Geology, v. 12, p. 387-410, https://doi.org/10.1111/j.1525-1314.1994. tb00031.x.

Pattison, D.R.M., and DeBuhr, C.L., 2015, Petrology of metapelites in the Bugaboo aureole, British Columbia, Canada: Journal of Metamorphic Geology, v. 33, p. 437-462, https://doi.org/10.1111/jmg.12128.

Pattison, D.R.M., and Seitz, J.D., 2012, Stabilization of garnet in metamorphosed altered turbidites near the St. Eugene lead-zinc deposit, southeastern British 
Columbia: Equilibrium and kinetic controls: Lithos, v. 134-135, p. 221-235, https://doi.org/10.1016/j.lithos.2011.12.007.

Pattison, D.R.M., and Tinkham, D.K., 2009, Interplay between equilibrium and kinetics in prograde metamorphism of pelites: an example from the Nelson aureole, British Columbia: Journal of Metamorphic Geology, v. 27, p. 249-279, https://doi.org/10.1111/j.1525-1314.2009.00816.x.

Pattison, D.R.M., Spear, F.S., Debuhr, C.L., Cheney, J.T., and Guidotti, C.V., 2002, Thermodynamic modelling of the reaction muscovite+cordierite $\rightarrow$ $\mathrm{Al}_{2} \mathrm{SiO}_{5}+$ biotite + quartz $+\mathrm{H}_{2} \mathrm{O}$ : constraints from natural assemblages and implications for the metapelitic petrogenetic grid: Journal of Metamorphic Geology, v. 20 , p. 99-118, https://doi.org/10.1046/j.0263-4929. 2001.356.356.x.

Pattison, D.R.M., Chacko, T., Farquhar, J., and McFarlane, C.R.M., 2003, Temperatures of granulite-facies metamorphism: Constraints from experimental phase equilibria and thermobarometry corrected for retrograde exchange: Journal of Petrology, v. 44, p. 867-900, https://doi.org/10.1093/petrology/44.5.867.

Pattison, D.R.M., de Capitani, C., and Gaidies, F., 2011, Petrological consequences of variations in metamorphic reaction affinity: Journal of Metamorphic Geology, v. 29, p. 953-977, https://doi.org/10.1111/j.1525-1314.2011.00950.x.

Pearce, M.A., White, A.J.R., and Gazley, M.F., 2015a, TCInvestigator: automated calculation of mineral mode and composition contours for THERMOCALC pseudosections: Journal of Metamorphic Geology, v. 33, p. 413-425, https://doi.org/ 10.1111/jmg.12126.

Pearce, M.A., White, A.J.R., Fisher, L.A., Hough, R.M., and Cleverley, J.S., 2015b, Gold deposition caused by carbonation of biotite during late-stage fluid flow: Lithos, v. 239, p. 114-127, https://doi.org/10.1016/j.lithos.2015.10.010.

Phillips, G.N., and Powell, R., 2010, Formation of gold deposits: a metamorphic devolatilization model: Journal of Metamorphic Geology, v. 28, p. 689-718, https://doi.org/10.1111/j.1525-1314.2010.00887.x.

Powell, R., 1978, Equilibrium Thermodynamics in Petrology, An Introduction: Harper \& Row Ltd, London, 284 p.

Powell, R., 1985, Geothermometry and geobarometry: a discussion: Journal of the Geological Society, v. 142, p. 29-38, https://doi.org/10.1144/gsigs.142.1.0029.

Powell, R., 1991, Metamorphic Mineral Equilibria Short Course: Course Notes: University of Melbourne. Available from: http://www.metamorph.geo.unimainz.de/thermocalc/documentation/introphasediagrams/index.html.

Powell, R., and Holland, T.J.B., 1988, An internally consistent dataset with uncertainties and correlations: 3. Applications to geobarometry, worked examples and a computer program: Journal of Metamorphic Geology, v. 6, p. 173-204, https://doi.org/10.1111/j.1525-1314.1988.tb00415.x.

Powell, R., and Holland, T.J.B., 2008, On thermobarometry: Journal of Metamorphic Geology, v. 26, p. 155-179, https://doi.org/10.1111/j.1525-1314.2007. 00756.x.

Powell, R., Holland, T., and Worley, B., 1998, Calculating phase diagrams involving solid solutions via non-linear equations, with examples using THERMOCALC: Journal of Metamorphic Geology, v. 16, p. 577-588, https://doi.org/10.1111/ j.1525-1314.1998.00157.x.

Powell, R., Guiraud, M., and White, R.W., 2005, Truth and beauty in metamorphic phase-equilibria: conjugate variables and phase diagrams: The Canadian Mineralogist, v. 43, p. 21-33, https://doi.org/10.2113/gscanmin.43.1.21

Ridley, J., and Thompson, A.B., 1986, The role of mineral kinetics in the development of metamorphic microtexture, in Walther, J.V., and Wood, B.J., eds., FluidRock Interactions During Metamorphism: Springer, New York, p. 154-193.

Riesco, M., Stüwe, K., Reche, J., and Martinez, F.J., 2004, Silica depleted melting of pelites. Petrogenetic grid and application to the Susqueda Aureole, Spain: Journal of Metamorphic Geology, v. 22, p. 475-494, https://doi.org/10.1111/ j.1525-1314.2004.00527.x

Riesco, M., Stüwe, K., and Reche, J., 2005, Formation of corundum in metapelites around ultramafic bodies. An example from the Saualpe region, Eastern Alps: Mineralogy and Petrology, v. 83, p. 1-25, https://doi.org/10.1007/s00710-004$0062-4$.

Rosenberg, C.L., and Handy, M.R., 2005, Experimental deformation of partially melted granite revisited: implications for the continental crust: Journal of Metamorphic Geology, v. 23, p. 19-28, https://doi.org/10.1111/j.1525-1314.2005. 00555.x.

Rubatto, D., Williams, I.S., and Buick, I.S., 2001, Zircon and monazite response to prograde metamorphism in the Reynolds Range, central Australia: Contributions to Mineralogy and Petrology, v. 140, p. 458-468, https://doi.org/ 10.1007/PL00007673

Rubie, D.C., 1998, Disequilibrium during metamorphism: the role of nucleation kinetics, in Treloar, P.J., and O'Brien, P.J., eds., What Drives Metamorphism and Metamorphic Reactions?: Geological Society, London, Special Publications, v. 138, p. 199-214, https://doi.org/10.1144/GSL.SP.1996.138.01.12.

Schaltegger, U., 2007, Hydrothermal Zircon: Elements, v. 3, p. 51-79, https://doi.org/10.2113/gselements.3.1.51.

Skora, S., Blundy, J.D., Brooker, R.A., Green, E.C.R., de Hoog, J.C.M., and Connolly, J.A.D., 2015, Hydrous phase relations and trace element partitioning behaviour in calcareous sediments at subduction-zone conditions: Journal of Petrology, v. 56, p. 953-980, https://doi.org/10.1093/petrology/egv024

Spear, F.S., 1995, Metamorphic phase equilibria and Pressure-Temperature-Time paths: Mineralogical Society of America, Washington, DC, 799 p.

Spear, F.S., 2010, Monazite-allanite phase relations in metapelites: Chemical Geology, v. 279, p. 55-62, https://doi.org/10.1016/j.chemgeo.2010.10.004

Spear, F.S., and Cheney, J.T., 1989, A petrogenetic grid for pelitic schists in the system $\mathrm{SiO}_{2}-\mathrm{Al}_{2} \mathrm{O}_{3}-\mathrm{FeO}-\mathrm{MgO}-\mathrm{K}_{2} \mathrm{O}-\mathrm{H}_{2} \mathrm{O}$ : Contributions to Mineralogy and Petrology, v. 101, p. 149-164, https://doi.org/10.1007/BF00375302.

Spear, F.S., and Florence, F.P., 1992, Thermobarometry in granulites: pitfalls and new approaches: Precambrian Research, v. 55, p. 209-241, https://doi.org/10.1016/ 0301-9268(92)90025-J.

Spear, F.S., and Pyle, J.M., 2010, Theoretical modeling of monazite growth in a lowCa metapelite: Chemical Geology, v. 273, p. 111-119, https://doi.org/10.1016/ j.chemgeo.2010.02.016.

Spear, F.S., Kohn, M.J., and Cheney, J.T., 1999, $P-T$ paths from anatectic pelites: Contributions to Mineralogy and Petrology, v. 134, p. 17-32, https://doi.org/ $10.1007 / \mathrm{s} 004100050466$

Spear, F.S., Pattison, D.R.M., and Cheney, J.T., 2016, The metamorphosis of metamorphic petrology: Geological Society of America Special Papers, v. 523, p. SPE523-02, https://doi.org/10.1130/2016.2523(02)

Stepanov, A.S., Hermann, J., Rubatto, D., and Rapp, R.P., 2012, Experimental study of monazite/melt partitioning with implications for the REE, Th and U geochemistry of crustal rocks: Chemical Geology, v. 300-301, p. 200-220, https://doi.org/10.1016/j.chemgeo.2012.01.007.

Stevens, L.M., Baldwin, J.A., Cottle, J.M., and Kylander-Clark, A.R.C., 2015, Phase equilibria modelling and LASS monazite petrochronology: $P-T-t$ constraints on the evolution of the Priest River core complex, northern Idaho: Journal of Metamorphic Geology, v. 33, p. 385-411, https://doi.org/10.1111/jmg.12125.

Stixrude, L., and Lithgow-Bertelloni, C., 2005, Thermodynamics of mantle minerals - I. Physical properties: Geophysical Journal International, v. 162, p. 610-632, https://doi.org/10.1111/j.1365-246X.2005.02642.x.

Stixrude, L., and Lithgow-Bertelloni, C., 2007, Influence of phase transformations on lateral heterogeneity and dynamics in Earth's mantle: Earth and Planetary Science Letters, v. 263, p. 45-55, https://doi.org/10.1016/j.epsl.2007.08.027.

Stixrude, L., and Lithgow-Bertelloni, C., 2011, Thermodynamics of mantle minerals - II. Phase equilibria: Geophysical Journal International, v. 184, p. 1180-1213, https://doi.org/10.1111/j.1365-246X.2010.04890.x.

Stüwe, K., and Powell, R., 1995, PT Paths from modal proportions: application to the Koralm Complex, Eastern Alps: Contributions to Mineralogy and Petrology, v. 119, p. 83-93, https://doi.org/10.1007/BF00310719.

Symmes, G.H., and Ferry, J.M., 1992, The effect of whole-rock MnO content on the stability of garnet in pelitic schists during metamorphism: Journal of Metamorphic Geology, v. 10, p. 221-237, https://doi.org/10.1111/j.1525-1314.1992. tb00080.x.

Thompson, A.B., and Algor, J.R., 1977, Model systems for anatexis of pelitic rocks: Contributions to Mineralogy and Petrology, v. 63, p. 247-269, https://doi.org/ 10.1007/BF00375575.

Thompson, A.B., and England, P.C., 1984, Pressure-Temperature-Time paths of regional metamorphism II. Their inference and interpretation using mineral assemblages in metamorphic rocks: Journal of Petrology, v. 25, p. 929-955, https://doi.org/10.1093/petrology/25.4.929.

Thompson, A.B., and Tracy, R.J., 1979, Model systems for anatexis of pelitic rocks: Contributions to Mineralogy and Petrology, v. 70, p. 429-438, https://doi.org/ 10.1007/BF00371049.

Thompson, J.B., 1957, The graphical analysis of mineral assemblages in pelitic schists: American Mineralogist, v. 42, p. 842-858.

Tinkham, D.K., and Ghent, E.D., 2005, Estimating P-T conditions of garnet growth with isochemical phase-diagram sections and the problem of effective bulk-composition: The Canadian Mineralogist, v. 43, p. 35-50, https://doi.org/10.2113/gscanmin.43.1.35.

Tinkham, D.K., Zuluaga, C.A., and Stowell, H.H., 2003, Metapelite phase equilibria modeling in MnNCKFMASH: The effect of variable $\mathrm{Al}_{2} \mathrm{O}_{3}$ and $\mathrm{MgO} /(\mathrm{MgO}+$ $\mathrm{FeO}$ ) on mineral stability: American Mineralogist, v. 88, p. 1174-1174

Tomkins, A.G., and Evans, K.A., 2015, Separate zones of sulfate and sulfide release from subducted mafic oceanic crust: Earth and Planetary Science Letters, v. 428, p. 73-83, https://doi.org/10.1016/j.epsl.2015.07.028.

Vernon, R.H., and Clarke, G.L., 2008, Principles of Metamorphic Petrology: Cambridge University Press, $478 \mathrm{p}$.

Vernon, R.H., White, R.W., and Clarke, G.L., 2008, False metamorphic events 
inferred from misinterpretation of microstructural evidence and $P-T$ data: Journal of Metamorphic Geology, v. 26, p. 437-449, https://doi.org/10.1111/ j.1525-1314.2008.00762.x

Vigneresse, J.L., and Burg, J.P., 2000, Continuous vs. discontinuous melt segregation in migmatites: insights from a cellular automaton model: Terra Nova, v. 12, p. 188-192, https://doi.org/10.1046/j.1365-3121.2000.00299.x.

Vry, J.K., Powell, R., and Williams, J., 2008, Establishing the $P-T$ path for Alpine Schist, Southern Alps near Hokitika, New Zealand: Journal of Metamorphic Geology, v. 26, p. 81-97, https://doi.org/10.1111/j.1525-1314.2007.00746.x.

Waters, D.J., and Lovegrove, D.P., 2002, Assessing the extent of disequilibrium and overstepping of prograde metamorphic reactions in metapelites from the Bushveld Complex aureole, South Africa: Journal of Metamorphic Geology, v. 20, p. 135-149, https://doi.org/10.1046/j.0263-4929.2001.00350.x.

White, A.J.R., Waters, D.J., and Robb, L.J., 2013, The application of P-T-X $\left(\mathrm{CO}_{2}\right)$ modelling in constraining metamorphism and hydrothermal alteration at the Damang gold deposit, Ghana: Journal of Metamorphic Geology, v. 31, p. 937 961, https://doi.org/10.1111/jmg.12051.

White, A.J.R., Legras, M., Smith, R.E., and Nadoll, P., 2014c, Deformation-driven, regional-scale metasomatism in the Hamersley Basin, Western Australia: Journal of Metamorphic Geology, v. 32, p. 417-433, https://doi.org/10.1111/ jmg.12078.

White, R.W., and Powell, R., 2002, Melt loss and the preservation of granulite facies mineral assemblages: Journal of Metamorphic Geology, v. 20, p. 621-632, https://doi.org/10.1046/j.1525-1314.2002.00206_20_7.x.

White, R.W., Powell, R., and Phillips, G.N., 2003, A mineral equilibria study of the hydrothermal alteration in mafic greenschist facies rocks at Kalgoorlie, Western Australia: Journal of Metamorphic Geology, v. 21, p. 455-468, https://doi.org/10.1046/j.1525-1314.2003.00454.x.

White, R.W., Powell, R., and Halpin, J.A., 2004, Spatially-focussed melt formation in aluminous metapelites from Broken Hill, Australia: Journal of Metamorphic Geology, v. 22, p. 825-845, https://doi.org/10.1111/j.1525-1314.2004.00553.x.

White, R.W., Pomroy, N.E., and Powell, R., 2005, An in situ metatexite-diatexite transition in upper amphibolite facies rocks from Broken Hill, Australia: Journal of Metamorphic Geology, v. 23, p. 579-602, https://doi.org/10.1111/j.15251314.2005.00597.x.

White, R.W., Powell, R., and Holland, T.J.B., 2007, Progress relating to calculation of partial melting equilibria for metapelites: Journal of Metamorphic Geology, v 25, p. 511-527, https://doi.org/10.1111/j.1525-1314.2007.00711.x.

White, R.W., Powell, R., Holland, T.J.B., Johnson, T.E., and Green, E.C.R., 2014a, New mineral activity-composition relations for thermodynamic calculations in metapelitic systems: Journal of Metamorphic Geology, v. 32, p. 261-286, https://doi.org/10.1111/jmg.12071.

White, R.W., Powell, R., and Johnson, T.E., 2014b, The effect of Mn on mineral stability in metapelites revisited: new $a-x$ relations for manganese-bearing minerals: Journal of Metamorphic Geology, v. 32, p. 809-828, https://doi.org/ 10.1111/jmg.12095.

Whitney, D.L., Teyssier, C., Rey, P., and Buck, W.R., 2013, Continental and oceanic core complexes: Geological Society of America Bulletin, v. 125, p. 273-298, https://doi.org/10.1130/B30754.1.

Will, T.M., Powell, R., and Holland, T.J.B., 1990, A calculated petrogenetic grid for ultramafic rocks in the system $\mathrm{CaO}-\mathrm{FeO}-\mathrm{MgO}-\mathrm{Al}_{2} \mathrm{O}_{3}-\mathrm{SiO}_{2}-\mathrm{CO}_{2}-\mathrm{H}_{2} \mathrm{O}$ at low pressures: Contributions to Mineralogy and Petrology, v. 105, p. 347-358, https://doi.org/10.1007/BF00306544.

Wing, B.A., Ferry, J.M., and Harrison, T.M., 2003, Prograde destruction and formation of monazite and allanite during contact and regional metamorphism of pelites: petrology and geochronology: Contributions to Mineralogy and Petrology, v. 145, p. 228-250, https://doi.org/10.1007/s00410-003-0446-1.

Yakymchuk, C., 2017, Behaviour of apatite during partial melting of metapelites and consequences for prograde suprasolidus monazite growth: Lithos, v. 274-275, p. 421-426, https://doi.org/10.1016/j.lithos.2017.01.009.

Yakymchuk, C., and Brown, M., 2014a, Consequences of open-system melting in tectonics: Journal of the Geological Society, v. 171, p. 21-40, https://doi.org/10.1144/jgs2013-039.

Yakymchuk, C., and Brown, M., 2014b, Behaviour of zircon and monazite during crustal melting: Journal of the Geological Society, v. 171, p. 465-479, https://doi.org/10.1144/jgs2013-115.

Yakymchuk, C., Brown, M., Clark, C., Korhonen, F.., Piccoli, P.M., Siddoway, C.S. Taylor, R.J.M., and Vervoort, J.D., 2015, Decoding polyphase migmatites using geochronology and phase equilibria modelling: Journal of Metamorphic Geology, v. 33, p. 203-230, https://doi.org/10.1111/jmg.12117.

Yakymchuk, C., Clark, C., and White, R.W., 2017, Phase relations, reaction sequences and petrochronology: Reviews in Mineralogy and Geochemistry, (in press), https://doi.org/10.2138/rmg.2017.83.2.
Zen, E-A., 1966, Construction of pressure-temperature diagrams for multicomponent systems after the method of Schreinemakers-A geometric approach: USGS Bulletin 1225, 56 p.

Zuluaga, C.A., Stowell, H.H., and Tinkham, D.K., 2005, The effect of zoned garnet on metapelite pseudosection topology and calculated metamorphic $P-T$ paths: American Mineralogist, v. 90, p. 1619-1628, https://doi.org/10.2138/ am.2005.1741.

\section{Received November 2016}

Accepted as revised February 2017

First published on the web February 2017 

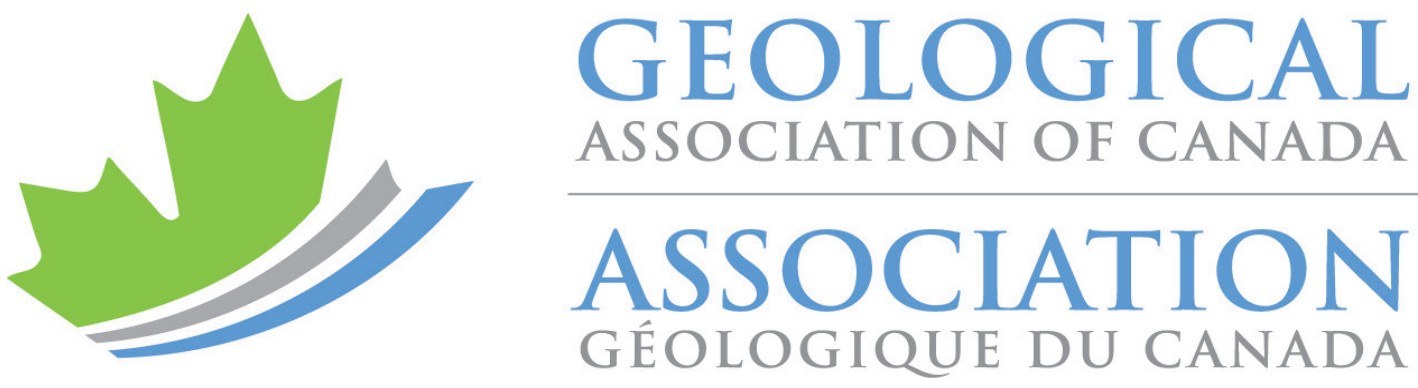

We SELL Books

Stirring the Pot: A Celebration of the Career of Paul F. Hoffman

Palaeontographica Canadiana series Geology of Mineral Resources Mineral Deposits of Canada Atlas of Alteration Ore Mineral Atlas

Facies Models 4

\section{We Host CONFERENCES}

Kingston, ON, 2017

kingstongacmac.ca

Vancouver, BC, 2018

rfg2018.org

We Publish A Journal

Geoscience Canada

\section{We AcknoWledge Distinction}

Logan Medal

W.W. Hutchison Medal

E.R.Ward Neale Medal

J. Willis Ambrose Medal

Mary-Claire Ward Geoscience Award

Yves Fortier Earth Science Journalism Award ...and many more!

SUPPORT US TODAY 7098647660 gac@mun.ca

www.gac.ca

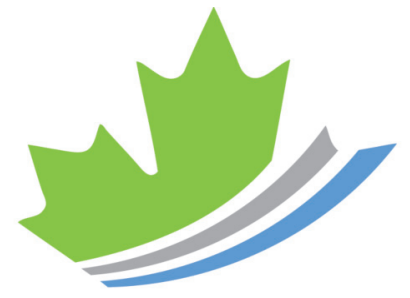

